\title{
THE IMPACT OF THE DIMENSIONS OF TRANSFORMATIONAL LEADERSHIP ON THE POST-ACQUISITION PERFORMANCE OF THE ACQUIRED COMPANY
}

\author{
Sladjana Savovic* \\ Faculty of Economics, University of Kragujevac, Kragujevac, The Republic of Serbia
}

\begin{abstract}
Mergers and acquisitions (M\&A) are the important mechanisms through which companies can achieve growth, gain access to new markets and diversify their activities. Although companies engage themselves in $M \& A s$ with optimism, empirical evidence shows that many M\&A transactions are not successful. Therefore, research is often focused on the identification of the ways to improve post-acquisition performance. One of the key success factors of M\&A is to provide adequate transformational leadership during the process of change, especially in the critical phase of the post-acquisition integration. A transformational leader should provide incentives and support to the employees in order for them to accept changes and focus on achieving challenging goals. This paper explores the impact of the different dimensions of transformational leadership on the post-acquisition performance based on the example of a company operating in the Republic of Serbia's retail sector, which was the subject of a cross-border acquisition. In order to ensure the adequate representativeness of the sample, a questionnaire was distributed in all parts of the company throughout the Republic of Serbia. The results of this study show that all the dimensions of transformational leadership positively impact post-acquisition performance. The "individual consideration" dimension of transformational leadership has the strongest impact on post-acquisition performance, whereas the "intellectual simulation" dimension has the weakest.
\end{abstract}

Keywords: transformational leadership, dimensions of transformational leadership, post-acquisition performance, acquired company

\section{JEL Classification: G34, M54, L25}

\section{INTRODUCTION}

In the last few decades, mergers and acquisitions have been the primary strategic options that companies

* Correspondence to: S. Savovic, Faculty of Economics, University of Kragujevac, Dj. Pucara 3, 34000 Kragujevac, The Republic of Serbia; e-mail: ssladjana@kg.ac.rs use in order to ensure their position in an increasingly competitive environment (Faulkner, Teerikangas \& Jospeh, 2012). Mergers and acquisitions are very complex organizational events with a large number of the factors that can lead to either their success or failure. One of the reasons why an M\&A fails lies in the negligence of the human-resources-related 
issues. The transactions of M\&As are traumatic events for employees due to possible layoffs, the introduction of new management styles and new business rules. M\&As increase employee uncertainty, which leads to less of a commitment to the company and the performing of organizational tasks. Hence, it is essential to ensure adequate transformational leadership, especially during the critical postacquisition phase (Waldman \& Mansour, 2009), in order to provide the necessary support and assistance to employees and help them to overcome problems. Transformational leadership implies "fundamentally changing the values, goals, and aspirations of followers, so that they perform their work because it is consistent with their values, as opposed to the expectation that they will be rewarded for their efforts" (MacKenzie, Podsakoff \& Rich, 2001, 118). Transformational leaders "have capabilities and skills to motivate employees to form a new way of thinking, destroying the existing paradigms and creating new ones"' (Savović, 2012, 200).

The four dimensions of transformational leadership are inspirational motivation, charisma or an idealized influence, individual consideration and an intellectual stimulation (Bass, 1999). inspirational motivation is the degree to which a leader articulates the vision that is appealing and inspirational to employees. The idealized influence is the ability of the leader to elicit pride, faith and respect (Covin, Kolenko, Sightler \& Tudor, 1997). Individual consideration refers to paying attention to each employee, or dealing with his/her specific problems. The intellectual stimulation is the behaviour of the leaders who develop the employees' ability and inclination to think about problems in a new way (Rafferty \& Griffin, 2004). Transformational leaders should provide employees with a clear picture or vision of the future, inspire them and provide them with the necessary support and help in their facing the challenges of change, thereby increasing employees' commitment to execute tasks more efficiently.

Research in the relationship between transformational leadership and performance has attracted the interest of many authors (Judge \& Piccolo, 2004; Menges, Walter, Vogel \& Bruch 2011; Carter, Armenakis, Field \& Mossholder 2012; Braun, Peus, Weisweiler \& Frey, 2013). However, only a few studies have researched the impact of transformational leadership on postacquisition performance (Nemanich \& Keller, 2007; Nemanich \& Vera, 2009). These studies are mostly focused on developed markets, while the research related to transitional economies is limited.

The subject of the research study carried out in this paper is transformational leadership and its effects on post-acquisition performance.

The purpose of this paper is to examine the impact of the different dimensions of transformational leadership on the post-acquisition performance of the acquired company.

In accordance with the defined subject and the purpose of the research, the basic scientific hypothesis of this paper is that the dimensions of transformation leadership have a positive influence on the postacquisition performance of the acquired company.

Having in mind the defined subject and the purpose of the research, as well as the basic research hypothesis, qualitative and quantitative methodologies have been applied in the paper. The application of the qualitative methodology is reflected in consulting the relevant literature so as to create the theoretical basis for applying the quantitative methodology, through which the research hypotheses have been tested. The emphasis on the quantitative methodology is evident in the literature on M\&As since it allows the consideration of the relationship between various independent and dependent variables (usually postacquisition performance) (Schoenberg, 2006). The empirical research was conducted on the example of the company operating as a leader in the sector of the retail trade of consumer goods, which was the subject of a cross-border acquisition in 2011. The data collection was carried out through a structured questionnaire, distributed to employees. The data analysis was conducted by using various quantitative statistical methods and techniques. An analysis of the reliability and internal consistency of the variables was performed. The hypotheses were tested by the hierarchical regression.

The paper is structured into five sections. After the Introduction Section, the paper provides an 
overview of the literature, which sets the basis for the formulation of the research hypotheses. The third section explains the methodology of the research. Thereafter, the fourth section presents the results of the empirical research. Finally, in the fifth section, conclusions are given, the contributions of the paper are emphasized and the directions for future research are set out.

\section{LITERATURE REVIEW}

\section{The Concept of Transformational Leadership}

Among the different perspectives of leadership, transformational leadership is often associated with managerial effectiveness during organizational changes (Carter et al, 2012). Transformational leadership emerged in the 1980s, together with a great wave of the organizational changes that needed to be implemented in the short term and that could only be made by exceptionally capable leaders. In situations of complex changes, transformational leadership is more effective than transactional leadership, which is a more conventional leadership style. Transactional leaders influence employees by rewarding their accomplishments and undertaking corrective actions if necessary. Transformational leadership is most often used to describe the leaders who face challenges and motivate employees to think differently about their processes, procedures, knowledge and decisionmaking. These leaders' task is to communicate a well-articulated vision, create a sense of belonging and encourage their employees to adapt to change. B. Bass (1999) points out that transformational and transactional leadership are two separate concepts, but it is best for leaders to have the characteristics of both transformational and transactional leaders.

Transformational leaders communicate a vision that creates enthusiasm for employees (inspirational motivation), provide support to their subordinates through their charisma (the idealized influence), pay attention to employees' individual needs and respond to their problems (individual consideration), encourage different thinking and innovation within the organization (the intellectual stimulation). The purpose of inspiring leadership is to build a desire for excellence and also accept change with enthusiasm and trust (Sitkin \& Pablo, 2005). Transformational leaders convey a vision with a strong emotional charge, which represents the necessary driving force and is important for ensuring high employee engagement and commitment (Stojanović Aleksić, 2006). Additionally, in the acquired company, inspirational leadership increases the employees' commitment because it enables them to more easily understand the new organizational environment (Schweizer \& Patzelt, 2012). By developing the feeling that challenging goals are achievable and that the company has the capability of achieving them leaders are able to motivate and inspire employees to approach all possible obstacles with enthusiasm so that such obstacles can be easily overcome.

Charisma (the idealized influence) can be defined as the ability to create the great symbolic power which employees want to identify themselves with (Covin et al, 1997). Employees feel strong admiration, respect and trust towards the charismatic leader. D. Nadler and M. Tushman (1990) describe a "charismatic leader" as someone who possesses specific qualities and the ability to mobilize and sustain activity in the organization through concrete activities and personal characteristics. Charismatic leaders inspire employees and demonstrate determination in making changes; they are trusting and represent a model of identification. Such characteristics enable them to influence the employees' an increasing commitment to their organization and their greater motivation towards achieving better performances (Waldman \& Mansour, 2009).

Individual consideration is the degree to which a leader pays attention to the employees' needs, acts as a mentor and responds to the employees' problems and their needs (Judge \& Piccolo, 2004). L. M. Marks and H. P. Mirvis (1986) point out that the employees of acquired companies go through great psychological shocks during acquisitions and therefore they need support. By providing each employee individually with the resources and training, encouragement 
and necessary information, the leader works so as to develop their sense of acceptance, security and personal effectiveness.

Intellectual stimulation is the degree to which a leader faces assumptions, takes risks and offers employees ideas. Leaders with this feature stimulate and encourage creativity among employees. Creative thinking is of particular importance since there is a need to reject the routines and norms of the behaviour that existed in the previous organization and adopt new habits. By providing intellectual stimulation, transformational leaders encourage employees to adopt the research process of thinking and to also think about old problems in a new way. By expressing high expectations and showing confidence in the ability of their employees, transformational leaders influence the development of the employees' commitment to achieving long-term goals. In this way, the focus is shifted from short-term goals and immediate solutions to long-term goals and fundamental solutions (Jung, Chow \& Wu, 2003).

\section{The Measurement of Post-Acquisition Performance}

In the last twenty years, a large number of studies have been focused on research into post- acquisition performance (Ravensraft \& Scherer, 1989; Morosini \& Singh, 1994; Lu, 2004; Schoenberg, 2006; Martynova \& Renneboog, 2008). These studies rely on the different measurement of post-acquisition performance, and the most common approaches are: the stock-marketbased measurement (Sudarsanam \& Mahate, 2003; Tuch \& O'Sullivan, 2007), the accounting-based measures (Ravensraft \& Scherer, 1989; Healy, Palepu \& Ruback, 1992; Lu, 2004), as well as the measures based on the subjective assessments of managers (Datta, 1991; Homburg \& Bucerius, 2006). The studies applying the stock-market-based measurement are the event studies that observe the evolution of a company's stock prices in days or months around the announcement of the acquisition (a short-term study), as well as the evolution of a company's stock prices over a long period of time, usually several months or years after the acquisition (a long-term study). The methodology of the event studies "is based on the assumption that the capital market operates efficiently, which means that share prices react to new information in a timely and unbiased fashion, and that changes in the company share price reflect the value of the acquisition" (Cordin \& Christman, 2002, as cited in Savović, 2016, 82). The model observing the evolution of a company's share prices is based on the determining of the abnormal return. A significant problem of these performance measures is that these measures do not apply to the companies that are not quoted on the stock exchange. Additionally, stock price changes may not only be the result of acquisitions, but they may be caused by other factors as well. In addition, the existence of the periods in which shares are not traded, as well as the overlapping of the multiple events of acquisitions, can impair the reliability of long-term studies (Tuch \& O'Sullivan, 2007). In the event studies, the researchers have found that the acquired company's shareholders' returns are positive and significantly high because of the large premiums paid. The shareholders of acquired companies obtain large premiums, 20-40\% on average, compared with the share price before the announcement of the offer (Goergen \& Renneboog, 2004). A. Fatemi, I. Fooladi, and N. Garehkoolchian (2017) investigate the short-term effects of acquisitions in Japan and, on the basis of the results of the survey, conclude that the shareholders of the acquired companies obtain positive returns. The results of the studies regarding the impact on the acquiring companies' shareholders are inconclusive. Some studies show positive returns, whereas the other ones report negative returns. J. Li, P. Li and B. Wang $(2016,481)$ find that, in cross-border M\&As, "involving listed Chinese firms as acquirers, on average, the acquirer's stock price rises 2-4\%". On the other hand, S. Sudarsanam and A. Mahate (2003) point to the fact that the acquiring companies' shareholders obtain negative abnormal returns in the short term.

The stock-market-based measures of performance cannot evaluate the impact of acquisitions on costs, revenues, profits and cash flows, although the strategy of the acquisition is often aimed at improving these variables as a result of the expected strengthening of 
the competitive position. Hence, the accounting-based measures have a special significance. Accountingbased studies analyse the accounting performance of a company by comparing certain indicators, most often the return-on-assets ratio, the returnon-equity ratio, the operating profit margin and the net profit margin, prior to and after acquisitions. I. Thanos and V. Papadakis $(2012,120)$ point out that "the major advantage of accounting-based measures is that they measure actual performance as reported in the annual financial statements and not investors' expectations for the future". The main disadvantages of the accounting-based measures are that they reflect performance in the past and that the application of different accounting measures can make the results of research studies difficult to compare (Savović, 2016). The results obtained in the accounting-based studies are different. R. Rao-Nicholson, J. Salaber, and T. Hiep Cao $(2016,373)$ examined the performance of companies in emerging markets and they found that "industry-adjusted operating performance tends to decline in the three years following an M\&A". D. S. Sharma and J. Ho (2002) analysed the effects of Australian acquisitions on accounting performance and showed that corporate acquisitions did not lead to improved post-acquisition performance. On the other hand, P. Guest, M. Bild and M. Runsten (2010) analysed acquisitions in the UK and pointed out that the companies improved their profitability in the post-acquisition period.

The third group of the studies uses the subjective assessments of the managers for measuring postacquisition performance. This approach is applied when objective data are difficult to obtain. Managers fill in the questionnaires assessing financial and non-financial performance based on their personal understanding of the current situation in the company. Such performance evaluations can be a matter of managers' personal biases when the performance of the company is assessed by one respondent. Therefore, it is necessary that a larger number of respondents should be used in a performance assessment and that it should be ensured that the managers assessing performance are well aware of the company's situation and that they are familiar with the complete history of the acquisitions. If these conditions are met, the subjective assessments made by managers have an advantage over other performance measurement approaches because they allow the multidimensional measurement of post-acquisition performance by including both financial and non-financial performance. Based on the literature review, in particular on the studies using subjective performance criteria, I. Thanos and V. Papadakis (2012) conclude that on average 45$60 \%$ of acquisitions do not improve post-acquisition performance.

\section{Transformational Leadership and Post- Acquisition Performance}

Transformational leadership leads to a reduction in uncertainties and the development of the feelings of acceptance among employees, thus increasing their commitment to the organization, which is an essential prerequisite for improving company performance. Some studies have investigated the impact of transformational leadership on company performance (Garcia-Morales, Llorens-Montes \& Verdu-Jover, 2008; Wang, Tsui \& Xin, 2011). V. J. Garcia-Morales, F. J. Llorens-Montes and A. J. VerduJover (2008) emphasize the fact that transformational leadership improves organizational performance. The study carried out by T. Wang, A. Tsui and K. Xin (2011) showed that transformational leadership had a positive impact on the performance of a company.

Some studies have examined the relationship between the different dimensions of transformational leadership and performance (Podsakoff, MacKenzie, Moorman \& Fetter, 1990; Howell \& Avolio, 1993; Nemanich \& Keller, 2007; Rafferty \& Griffin, 2014; Babić, Savović \& Domanović, 2014). L. Nemanich and R. Keller (2007) investigated the influence of transformational leadership on the acceptance of acquisitions, employees' satisfaction and employees' performance. The results of the study have shown that transformational leadership has a positive impact on all dependent variables. The one dimension of transformational leadership (the idealized impact) has the greatest influence on the acceptance of 
acquisitions by employees, whereas the other dimension of transformational leadership (individual consideration) has the greatest impact on employees' performance. A study conducted by A. Rafferty and M. Griffin (2004) has shown that the two dimensions of transformational leadership (inspirational communication and the intellectual stimulation) have a positive impact on the employees' commitment to the organization. While the intellectual stimulation can increase the level of stress in the workplace (Podsakoff et al, 1990), employees still feel valuable when encouraged to contribute to the organization. Transferring positive and encouraging messages positively affects the employees' emotional connection with the company and strengthens their faith in their own ability to perform tasks. V. Babić, S, Savović and V. Domanović (2014) emphasize the fact that leaders' inspiration and encouragement of employees, as well as their reaction to the employee's problems (individual consideration), have a positive impact on post-acquisition performance. J. M. Howell and B. J. Avolio (1993) point out that the intellectual stimulation provided by leaders positively affects performance when there is an innovation-supportive climate. The intellectual stimulation enhances employees' ability to design, realize and analyse problems and improve the quality of solutions, which positively reflects on company performance.

In accordance with the review of the relevant literature, the formulated research hypotheses assume that the dimensions of transformational leadership have a positive impact on post-acquisition performance.

H1: By inspiring and encouraging their employees, transformational leaders positively influence the post-acquisition performance of the acquired company.

H2: Transformational leaders use their charisma to encourage employees to accept change, which positively influences the post-acquisition performance of the acquired company.

H3: Through their individual consideration of each employee, transformational leaders positively influence the post-acquisition performance of the acquired company.
H4: Through the intellectual stimulation of their employees, transformational leaders positively influence the post-acquisition performance of the acquired company.

\section{METHODS}

The research hypotheses will be tested on the case of a company acquired in 2011. The data were being collected during 2013 as a part of wider research efforts. Prior to conducting the research, the management of the acquired company had been contacted in order to be explained the research objectives to so that we could receive their approval for distributing the questionnaire to their employees. The management team approved the research provided that the researcher should submit the results of the survey to the company. The management of the company recognized the importance of carrying out such a research study for its own needs. Therefore, they tried to ensure the representativeness of the sample by distributing the questionnaires in all the parts of the Republic of Serbia which the company operates in. The total number of the employees in the company is 6357 and the survey was conducted on a sample of 344 employees, which accounts for 5.41\%. As shown in Table 1, regarding the gender, there are predominantly more women than men, ranking from $56.4 \%$ for the women and $28.2 \%$ for the men, thereby stressing the lack of a response to this sociodemographical aspect (15.4\%). Regarding the age, the majority of the respondents are between 26 and 35 years of age (33.1\%), as well as between 36 and 45 years of age (30.8\%). Observing work experience, there is a uniform representation of the respondents with less experience: up to 5 years (20.4\%), between 6 and 10 years (20.9\%) and between 11 and 15 years (19.8\%), whereas the respondents with longer work experience participate to a slightly lesser extent: between 16 and 25 years $(12.5 \%)$ and over 25 years (15.1\%). Regarding the position, $64.2 \%$ of the respondents are in the operating positions, $12.5 \%$ are in the managerial positions and $23.3 \%$ did not respond at all. 
Table 1 The characteristics of the sample

\begin{tabular}{|c|c|c|}
\hline Variable & Frequency & $\%$ of Total \\
\hline \multicolumn{3}{|l|}{ Gender } \\
\hline Male & 97 & 28.2 \\
\hline Female & 194 & 56.4 \\
\hline No response & 53 & 15.4 \\
\hline \multicolumn{3}{|l|}{ Age distribution } \\
\hline $18-25$ & 20 & 5.8 \\
\hline $26-35$ & 114 & 33.1 \\
\hline $36-45$ & 106 & 30.8 \\
\hline $46-55$ & 54 & 15.7 \\
\hline$>55$ & 9 & 2.6 \\
\hline No response & 1 & 11.9 \\
\hline \multicolumn{3}{|l|}{ Years of work experience } \\
\hline$<5$ & 70 & 20.4 \\
\hline $6-10$ & 72 & 20.9 \\
\hline $11-15$ & 68 & 19.8 \\
\hline $16-25$ & 43 & 12.5 \\
\hline$>25$ & 52 & 15.1 \\
\hline No response & 39 & 11.3 \\
\hline \multicolumn{3}{|l|}{ Position } \\
\hline $\begin{array}{l}\text { Managerial positions (top, } \\
\text { middle and operative } \\
\text { management) }\end{array}$ & 43 & 12.5 \\
\hline Operating positions & 221 & 64.2 \\
\hline No response & 80 & 23.3 \\
\hline
\end{tabular}

Source: Author

The data were analysed applying the Statistical Package for Social Sciences - SPSS, Version 20.0. The reliability and internal consistency of the variables was measured by using Cronbach's Alpha Coefficient. Descriptive statistics were used to measure the central tendency (the arithmetic mean) and variability (the standard deviation). The hypotheses were tested by using the linear regression.

The independent variables, i.e. the dimensions of transformational leadership, were measured on the basis of a modified Multifactor Leadership
Questionnaire (Bass \& Avolio, 2000). These variables were evaluated by all the respondents $(n=344)$. The dependent variable, i.e. post-acquisition performance, was measured by the subjective perceptions of the managers who expressed the degree of their agreement with the nine statements related to financial and non-financial performance. This variable was not evaluated by all the respondents, but only by the respondents holding the managerial positions ( $\mathrm{n}=$ 43). The five-step Likert scale was used, which shows the degree of the respondents' agreement with the statements. The respondents had a choice of answers from 1 - I do not agree at all - to 5 - I fully agree. Table 2 shows the model variables and the statements, on the basis of which the variables were measured.

\section{RESULTS}

Table 3 shows the means, the standard deviations and the coefficients of Cronbach's Alpha for the analysed variables. The values of the means of the dimension of transformational leadership are greater than 3 , meaning that the employees of the acquired companies are relatively satisfied with the support they have received from the leaders.

The employees had the most positive assessment of the two dimensions of transformational leadership - inspirational motivation (the mean $=3.38$ ) and the idealized influence (the mean $=3.30$ ); somewhat lower was their estimation of the intellectual stimulation (the mean = 3.16), whereas the lowest was that for the dimension of individual consideration (the mean $=3.06$ ). This means that the employees were more satisfied with the support of the leaders in terms of their inspiration and encouragement to accept change, whereas they were less satisfied with their support regarding the overcoming of possible problems during the change process. The value of the arithmetic mean of the variable post-acquisition performance is below 3 (the mean=2.88), which means that a satisfactory performance improvement was not achieved in the period after the acquisition. 
Table 2 The model variables and the statements

\begin{tabular}{|c|c|}
\hline $\begin{array}{l}\text { Variables } \\
\text { Independent } \\
\text { variables }\end{array}$ & Statements \\
\hline $\begin{array}{l}\text { Inspirational } \\
\text { motivation }\end{array}$ & $\begin{array}{l}\mathrm{S}_{\mathrm{S}}: \text { The superior managers optimistically spoke about the future of the company. } \\
\mathrm{S}_{2}: \text { The superior managers explained to the employees what the common vision was and what the } \\
\text { development directions of the company were. } \\
\mathrm{S}_{3}: \text { The superior managers helped the employees to understand why it was important for the company } \\
\text { to be acquired by another company. } \\
\mathrm{S}_{4}: \text { Obtaining relevant information from the superior managers related to the future plans helped me to } \\
\text { overcome problems during the process of changes. }\end{array}$ \\
\hline $\begin{array}{l}\text { Idealized } \\
\text { influence }\end{array}$ & $\begin{array}{l}\mathrm{S}_{1}: \text { The superior managers served as positive examples and inspired the employees to implement } \\
\text { changes. } \\
\mathrm{S}^{2} \text { : The superior managers stimulated the employees through their personal example. } \\
\mathrm{S}^{2}: \text { The superior managers encouraged the employees to accept changes. } \\
\mathrm{S}_{4}^{3}: \text { The superior managers highlighted the importance and necessity of making changes in the company. }\end{array}$ \\
\hline $\begin{array}{l}\text { Individual } \\
\text { consideration }\end{array}$ & $\begin{array}{l}\mathrm{S}_{1}: \text { The direct support provided by the managers helped me to overcome the problems during the } \\
\text { process of changes. } \\
\mathrm{S}_{2}: \text { Different training programs were organized as a support to the adaptation of the employees to the } \\
\text { new circumstances in the company. } \\
\mathrm{S}_{3}: \text { The training course helped me to overcome the problems during the process of changes. }\end{array}$ \\
\hline
\end{tabular}

Intellectual $\quad S_{S}$ : The superior managers stimulated the innovative thinking of the employees.

stimulation $\quad S_{2}^{1}$ : The superior managers encouraged the employees to seek new ways of solving certain problems.

Dependent

variable

\begin{tabular}{|c|c|}
\hline $\begin{array}{l}\text { Post- } \\
\text { acquisition } \\
\text { performance }\end{array}$ & 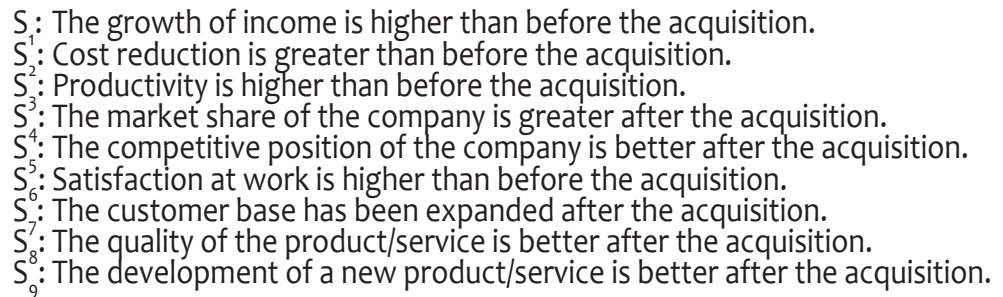 \\
\hline
\end{tabular}

Source: Author

Table 3 The means, the standard deviations and the coefficients of Cronbach's Alpha for the analysed variables

\begin{tabular}{lccc}
\hline Variables & Mean & S.D. & $\begin{array}{c}\text { Cronbach's } \\
\text { Alpha }\end{array}$ \\
\hline Inspirational motivation & 3.38 & 1.09 & 0.958 \\
Idealized influence & 3.30 & 1.19 & 0.943 \\
Individual consideration & 3.06 & 1.17 & 0.910 \\
$\begin{array}{l}\text { Intellectual stimulation } \\
\text { Post-acquisition }\end{array}$ & 3.16 & 1.25 & 0.951 \\
performance & 2.88 & 1.18 & 0.958 \\
\hline
\end{tabular}

Source: Author
The results of the analysis of the reliability and internal consistency of the variables showed that all the variables had a high level of reliability and internal consistency since the acceptable value of Cronbach's Alpha Coefficient was greater than 0.7. The highest degree of reliability is characteristic for the postacquisition performance variable $(\alpha=0.958)$, whereas all of the other variables had a high level of reliability (the intellectual stimulation: $\alpha=0.951$, inspirational motivation: $\alpha=0.943$, the idealized influence: $\alpha=0.902$ and individual consideration: $\alpha=0.910$ ).

Table 4 accounts for the results of the regression analyses that tested the influence of the different dimensions of transformational leadership on the 
post-acquisition performance of the company. The first hypothesis tests the impact of inspirational motivation on post-acquisition performance. The model is statistically significant $(\mathrm{F}=33.801 ; \mathrm{p}=0.00)$ and explains $45.7 \%$ of the variance of the dependent variable (adjusted R2 $=0.457$ ). The results of the regression analysis show that the first dimension of transformational leadership (inspirational motivation) has a positive impact on the postacquisition performance of the company $(\beta=0.686 ; p=$ 0.00 ). Based on the results of the analysis, Hypothesis H1 can be accepted. The results show that employees' inspiration boosted by transformational leaders has a positive impact on the post-acquisition performance of the acquired company.

The second hypothesis tests the influence of the second dimension of transformational leadership (the idealized impact) on the post-acquisition performance of the company. The model is statistically significant $(F=24.055 ; p=0.00)$ and explains $37.8 \%$ of the variance of the dependent variable (adjusted R2 $=0.378$ ). The results of the regression analysis show that the second dimension of transformational leadership (the idealized influence) has a positive impact on the postacquisition performance of the company $(\beta=0.628$; $p=0.00$ ). Having in mind the results of the analysis, Hypothesis $\mathrm{H} 2$ can be accepted. By providing a positive personal example and by encouraging employees to accept changes, transformational leaders have a positive impact on the post-acquisition performance of the acquired company.
The third hypothesis tests the influence of the third dimension of transformational leadership (individual consideration) on the post-acquisition performance of the company. The model is statistically significant ( $F$ $=40.842 ; \mathrm{p}=0.00$ ) and explains $51.2 \%$ of the variance of the dependent variable (adjusted R2 $=0.512$ ). The results of the regression analysis show that the third dimension of transformational leadership (individual consideration) has a positive impact on the postacquisition performance of the company $(\beta=0.724$; $p$ $=0.00$ ). In accordance with the results of the analysis, Hypothesis $\mathrm{H} 3$ can be accepted. By providing direct support to employees, transformational leaders have a positive impact on the post-acquisition performance of acquired companies.

The fourth hypothesis tests the impact of the fourth dimension of transformational leadership (the intellectual stimulation) on the post-acquisition performance of the company. The model is statistically significant $(\mathrm{F}=16.921 ; \mathrm{p}=0.00)$ and explains $29.0 \%$ of the variance of the dependent variable (adjusted $\mathrm{R} 2=$ 0.290). The results of the regression analysis show that the fourth dimension of transformational leadership (the intellectual stimulation) has a positive impact on the post-acquisition performance of the company $(\beta=0.555 ; p=0.00)$. According to the results of the analysis, Hypothesis H4 can be accepted. Through the intellectual stimulation and encouragement of innovative thinking among employees, transformational leaders positively influence the postacquisition performance of acquired companies.

Table 4 The impact of the dimension of transformational leadership on post-acquisition performance

\begin{tabular}{lcccccc}
\hline & $\mathrm{B}$ & $\mathrm{SE}$ & $\beta$ & $\mathrm{R}^{2}$ & adjusted $\mathrm{R}^{2}$ & $\mathrm{~F}$ \\
\hline Inspirational motivation & 0.608 & 0.105 & $0.686^{* *}$ & 0.471 & 0.457 & $33.801^{* *}$ \\
Idealized influence & 0.526 & 0.107 & $0.628^{* *}$ & 0.394 & 0.378 & $24.055^{* *}$ \\
Individual consideration & 0.676 & 0.106 & $0.724^{* *}$ & 0.525 & 0.512 & $40.842^{* *}$ \\
Intellectual stimulation & 0.466 & 0.113 & $0.555^{* *}$ & 0.308 & 0.290 & $16.921^{* *}$ \\
\hline
\end{tabular}

Note: ** The result is significant at the 0.01 level $(p<0.01)$

Source: Author 


\section{CONCLUSION}

In situations involving complex changes, such as the processes of company acquisitions, transformational leadership represents one of the key drivers of organizational performance. Transformational leaders communicate a vision that creates enthusiasm among employees; they provide their employees with support via their character (charisma), providing support to each individual employee through mentoring and teaching and encouraging different thinking and innovation within the organization. In this way, they act in the direction of reducing uncertainty for employees and developing the feelings of trust and interconnectedness.

The results of this research have shown that the dimensions of transformational leadership have a positive impact on post-acquisition performance. Having in mind the results of the conducted analyses, it can be concluded that, by inspiring their employees and spreading optimism, giving a positive example and individual support, as well as encouraging their employees to search for new ways to solve problems, transformational leaders contribute to employees' commitment to the company and to performed tasks, which positively affects the post-acquisition performance of the acquired company. Such results are consistent with the results of the other studies (Howell \& Avolio, 1993; Rafferty \& Griffin, 2004; Nemanich \& Keller, 2007) that have confirmed the existence of a positive impact of the dimensions of transformational leadership on company performance. The only difference in the results of this study compared to the previous research is that in the extent of the impact of the different dimensions of transformational leadership on company performance.

According to the results of the research, it can be concluded that the employees positively assessed the support of transformational leaders. The employees show a higher degree of satisfaction with inspirational support from transformational leaders, whereas the degree of satisfaction with the individual influence (overcoming possible problems during the process of change) is lower. The research results show that postacquisition performance in the observed company is not at a satisfactory level. Such a result can partially be explained by the fact that individual consideration, as a dimension of transformational leadership, has the highest impact on post-acquisition performance and simultaneously is the dimension ranked the lowest by the employees.

The research results have significant theoretical and practical implications. They contribute to the better understanding of the complex effects of transformational leadership on the postacquisition performance of the acquired company. Bearing in mind the fact that the previous studies in the field of transformational leadership were mostly focused on the impact of transformational leadership on performance, this study contributes in filling the research gap by focusing on the impact of transformational leadership on postacquisition performance. In addition, as research in transitional economies is limited, the results of the study contribute to the expansion of knowledge in the field of transformational leadership and postacquisition performance in the context of transitional economies. By connecting the results of the empirical research with the existing results of research in the world, it is possible to provide certain guidelines to the managers involved in the processes of company acquisitions. The companies that are going through the processes of complex changes should select and place the managers who have the characteristics of transformational leaders. If managers do not possess such characteristics, education and training should be organized in order to help them develop the skills of transformational leaders. In addition, as the results of the study have shown that individual consideration, i.e. the focus of the leader on providing support to each individual employee and reacting to their problems, has the highest impact on postacquisition performance, and as this dimension is ranked lower than the other ones by the employees, it is necessary for management to intensify support to employees, particularly paying attention to a reaction to employees' problems, providing them with help and organizing the training that will enable them to perform the required tasks more efficiently. The study can make a significant contribution to formulating the business policy of companies by emphasizing 
the fact that, in order to make a success in the periods of change, it is important to focus on human resources. The conclusions reached in this study can help managers to develop the necessary level of the commitment and trust among employees required to achieve challenging goals in the future.

The main limitation of this study is that the research was conducted in a single company. In order to draw general conclusions, an analysis should be carried out on a larger sample of companies. It would be useful to conduct a comparative analysis in several companies during the post-acquisition period in order to determine whether performance is better in the companies that have transformational leadership than in those that do not. The additional limitation of this research study is its reliance on only one data source, obtained by filling the questionnaire. Therefore, future research should ensure other sources of data, such as direct interviews with managers and financial statements, in order to enable a deeper analysis of the researched subject. Another limitation reflects in the fact that the research was conducted only two years after the acquisition, which is not a period of time long enough to estimate the overall effects of the acquisition. It is obvious that the period after the acquisition is the most critical and that in this period the support of leaders is the most important. Having in mind the previously stated limitation, future research should implement a research design that will enable us to study the effects of transformational leadership on post-acquisition performance successively, in different time periods, which would assume the implementation of longitudinal studies and would result in a deeper understanding of the of the researched subject.

\section{ACKNOWLEDGMENTS}

Babić, V., Savović, S., \& Domanović, V. (2014). Transformational leadership and post-acquisition performance in transitional economies. Journal of Organizational Change Management, 27(6), 856- 876. doi.org/10.1108/JOCM-02-2014-0028
Bass, B. (1999). Two decades of research and development in transformational leadership. European Journal of Work and Organizational Psychology, 8(1), 9-32. doi. org/10.1080/135943299398410

Bass, B. M., \& Avolio, B. J. (2000). MLQ Multifactor Leadership Questionnaire. Redwood City, CA: Mind Garden.

Braun, S., Peus, C., Weisweiler, S., \& Frey, D. (2013). Transformational leadership, job satisfaction, and team performance: A multilevel mediation model of trust. The Leadership Quarterly, 24(1), 270-283. doi.org/10.1016/j. leaqua.2012.11.006

Carter, M., Armenakis, A., Field, H., \& Mossholder, K. (2012). Transformational leadership, relationship quality, and employee performance during continuous incremental organizational change. Journal of Organizational Behavior, 34(7), 942-958. doi: 10.1002/job.1824

Cordin, M., \& Christman, P. (2002). A focus on resources in M\&A success: A literature review and research agenda to resolve two paradoxes. University of Virginia, 1-40. Retrieved October 10, 2014 from http://citeseerx.ist.psu.edu/ viewdoc/ download?doi=10.1.1.201.7773\&rep=rep1\&type=pdf

Covin, T., Kolenko, T., Sightler, K., \& Tudor, K. (1997). Leadership style and post-merger satisfaction. Journal of Management Development, 16(1), 22-33. doi. org $/ 10.1108 / 02621719710155454$

Datta, K. D. (1991). Organizational fit and acquisition performance - Effects of post-acquisition integration. In A. Risberg (Ed.). (2006). Mergers and Acquisitions A Critical Reader (pp. 53-69). London and New York: Taylor \& Francis Group. doi: 10.4324/9780203708071

Fatemi, A., Fooladi, I., \& Garehkoolchian, N. (2017). Gains from mergers and acquisitions in Japan. Global Finance Journal, 32, 166-178. doi.org/10.1016/j.gfj.2017.02.002

Faulkner, D., Teerikangas, S., \& Jospeh, R. (2012). The handbook of mergers and acquisitions. Oxford, Mississippi: Oxford University Press.

Garcia-Morales, V. J., Llorens-Montes, F. J., \& Verdu-Jover, A. J. (2008). The effects of transformational leadership on organizational performance through knowledge and innovation. British Journal of Management, 19(4), 299-319. doi: 10.1111/j.1467-8551.2007.00547.x 
Goergen, M., \& Renneboog, L. (2004). Shareholder wealth effects of European domestic and cross-border takeover bids. European Financial Management, 10(1), 9-45. doi: 10.1111/j.1468-036X.2004.00239.x

Guest, P., Bild, M., \& Runsten, M. (2010). The effect of takeovers on the fundamental value of acquireres. Accounting and Business Research, 40(4). 333-352. doi. org/10.1080/ 00014788.2010.9663409

Healy, P. M., Palepu, K. G., \& Ruback, R. S. (1992). Does corporate performance improve after mergers? Journal of Financial Economics, 31(2), 135-175. doi.org/10.1016/0304405X(92)90002-F

Homburg, C., \& Bucerius, M. (2006). Is speed of integration really a success factor of mergers and acquisitions? An analysis of role of internal and external relatedness. Strategic Management Journal, 27(4), 347-367. doi: 10.1002/ smj.520.

Howell, J. M., \& Avolio, B. J. (1993). Transformational leadership, transactional leadership, locus of control, and support for innovation: Key predictors of consolidated business-unit performance. Journal of Applied Psychology, 78(6), 891-902. doi.org/10.1037/0021-9010.78.6.891

Judge, T., \& Piccolo, R. (2004). Transformational and transactional leadership: A meta-analytic test of their relative validity. Journal of Applied Psychology, 89(5), 755768. doi: 10.1037/0021-9010.89.5.755

Jung, D., Chow, C., \& Wu, A. (2003). The role of transformational leadership in enhancing organizational innovation: Hypotheses and some preliminary findings. The Leadership Quarterly, 14(4-5), 525-544. doi.org/10.1016/ S1048- 9843(03)00050-X

Li, J., Li, P., \& Wang, B. (2016). Do cross-border acquisitions create value? Evidence from overseas acquisitions by Chinese firms. International Business Review, 25(2), 471483. doi.org/10.1016/j.ibusrev.2015.08.003

Lu, Q. (2004). Do mergers destroy value? Evidence from failed bids. Working Paper. Kellogg School of Management, Northwestern University.

MacKenzie, S., Podsakoff, P., \& Rich, G. (2001). Transformational and transactional leadership and salesperson performance. Journal of the Academy of Marketing Science, 29(2), 115-134. doi: $10.1177 / 03079459994506$
Marks, L. M., \& Mirvis, H. P. (1986). The merger syndrome, psychology today. In A. Risberg (Ed.). (2006). Mergers and Acquisition A Critical Reader (pp. 149-154). London and New York: Taylor \& Francis Group.

Martynova, M., \& Renneboog, L. (2008). A century of corporate takeovers: What have we learned and where do we stand? Journal of Banking and Finance, 32(10), 21482177. doi.org/10.1016/j.jbankfin.2007.12.038

Menges, J., Walter, F., Vogel, B., \& Bruch, H. (2011). Transformational leadership climate: Performance linkages, mechanisms, and boundary conditions at the organizational level. The Leadership Quarterly, 22(5), 893909. doi: 10.1016/j.leaqua.2011.07.010

Morosini, P., \& Singh, H. (1994). Post-cross-border acquisitions: Implementing 'national culture-compatible' strategies to improve performance. European Management Journal, 12(4), 390-400. doi: 10.1016/0263-2373(94)90025-6

Nadler, D., \& Tushman, M. (1990). Beyond the charismatic leader: Leadership and organizational change. California Management Review, 32(2), 77-97. doi.org/10.2307/41166606

Nemanich, L., \& Keller, R. (2007). Transformational leadership in an acquisition: A field study of employees. The Leadership Quarterly, 18(1), 49-68. doi: 10.1016/j. leaqua.2006.11.003

Nemanich, L., \& Vera, D. (2009). Transformational leadership and ambidexterity in the context of an acquisition. The Leadership Quarterly, 20(1), 19-33. doi: 10.1016/j. leaqua.2008.11.002

Podsakoff, P. M., MacKenzie, S. B., Moorman, R. H., \& Fetter, R. (1990). Transformational leader behaviors and their effects on followers' trust in leader, satisfaction, organizational citizenship behaviours. The Leadership Quarterly, 1(2), 107-142. doi: 10.1016/1048-9843(90)90009-7

Rafferty, A., \& Griffin, M. (2004). Dimensions of transformational leadership: Conceptual and empirical extensions. The Leadership Quarterly, 15(3), 329-354. doi: 10.1016/j. leaqua.2004.02.009

Rao-Nicholson, R., Salaber, J., \& Hiep Cao, T. (2016). Longterm performandce of mergers and acquisitions in ASEAN countries. Research in International Business and Finance, 36, 373-387. doi.org/10.1016/j.ribaf.2015.09.024 
Ravenscraft, D. J., \& Scherer, F. J. (1989). The profitability of mergers. International Journal of Industrial Organizations, 7(1), 101-116. doi.org/10.1016/0167-7187(89)90048-9

Savović, S. (2012). The importance of post-acquisition integration for value creation and success of mergers and acquisitions. Economic Horizons, 14(3), 195-207. doi: 10.5937/ ekonhor1203193S

Savović, S. (2016). Post-acquisition performance of acquired companies: Evidence from Republic of Serbia. Economic Annals, 61(209), 79-104. doi: 10.2298/EKA1609079S

Schoenberg, R. (2006). Measuring the performance of corporate acquisitions: An empirical comparison of alternative metrics. British Journal of Management, 17(4), 361-370. doi: 10.1111/j.1467-8551.2006.00488.x

Schweizer, L., \& Patzelt, H. (2012). Employee commitment in the post-acquisition integration process: The effect of integration speed and leadership. Scandinavian Journal of Management, 28(4), 298-310. doi.org/10.1016/j. scaman.2012.02.003

Sharma, D. S., \& Ho, J. (2002). The impact of acquisitions on operating performance: Some Australian evidence. Journal of Business Finance \& Accounting, 29(1-2), 155-200. doi.org/10.1111/1468-5957.00428

Sitkin, S., \& Pablo, A. (2005). The neglected importance of leadership in mergers and acquisitions. In G. K. Stahl, \& M. E. Mendenhall (Eds.). Mergers and Acquisitions. Managing Culture and Human Resource (pp. 208-223). Stanford, Calif: Stanford University Press.
Stojanović Aleksić, V. (2006). Liderstvo kao ključni faktor uspešnog sprovođenja organizacionih promena. Ekonomski horizonti, 8(1-2), 7-14.

Sudarsanam, S., \& Mahate, A. (2003). Glamour acquirers, method of payment and post-acquisition performance: the UK evidence. Journal of Business Finance and Accounting, 30(1-2), 299-341. doi: 10.1111/1468-5957.00494

Thanos, I., \& Papadakis, V. (2012). Unbundling acquisition performance: how do they perform and how can this be measured? In D. Faulkner, S. Teerikangas, \& R. Jospeh, (Eds.). The Handbook of Mergers and Acquisitions (pp. 114147). Oxford, Mississippi: Oxford University Press.

Tuch, C., \& O'Sullivan, N. (2007). The impact of acquisitions on firm performance: A review of the evidence. International Journal of Management Reviews, 9(2), 141-170. doi: 10.1111/j.1468-2370.2007.00206.x

Waldman, D. A., \& Mansour, J. (2009). Alternative forms of charismatic leadership in integration of mergers and acquisitions. The Leadership Quarterly, 20(2), 130-142. doi. org/10.1016/j.leaqua.2009.01.008

Wang, H., Tsui, A., \& Xin, K. (2011). CEO leadership behaviors, organizational performance, and employees' attitudes. The Leadership Quarterly, 22(1), 92-105. doi: 10.1016/j. leaqua.2010.12.009

Wang, H., Tsui, A., \& Xin, K. (2011). CEO leadership behaviors, organizational performance, and employees' attitudes. The Leadership Quarterly, 22(1), 92-105. doi:10.1016/j.leaqua.2010.12.009

Received on $16^{\text {th }}$ June 2017, after three revisions, accepted for publication on $23^{\text {rd }}$ August 2017. Published online on $25^{\text {th }}$ August 2017.

Sladjana Savovic is an Assistant Professor of Enterprise Economics at the Faculty of Economics, University of Kragujevac, the Republic of Serbia. She received her PhD deegre from the Faculty of Economics of the University of Kragujevac. The main areas of her research interests are mergers and acquisitions, post-acquisition integration and post-acquisition performance. 


\title{
UTICAJ DIMENZIJA TRANSFORMACIONOG LIDERSTVA NA POSTAKVIZICIONE PERFORMANSE PREUZETOG PREDUZEĆA
}

\author{
Slađana Savović* \\ Ekonomski fakultet Univerziteta u Kragujevcu
}

\begin{abstract}
Merdžeri i akvizicije predstavljaju dominantan način na koji preduzeća mogu da pristupaju novim tržištima, rastu i diverzifikuju svoje aktivnosti. Iako se ovim procesima pristupa sa optimizmom, empirijska istraživanja pokazuju da je veliki broj merdžera i akvizicija neuspešan. Otuda je u fokusu istraživanja identifikovanje načina za unapređenje postakvizicionih performansi preduzeća. Jedan od mogućih načina unapređenja postakvizicionih performansi jeste obezbediti adekvatno transformaciono liderstvo tokom procesa promena, posebno u kritičnoj postakvizicionoj fazi integracije. Transformacioni lideri treba da pruže podsticaj i podršku zaposlenima kako bi prihvatili promene i usmerili se ka ostvarivanju izazovnih ciljeva. Rad se bavi istraživanjem uticaja različitih dimenzija transformacionog liderstva na postakvizicione performanse na primeru preduzeća koje posluje u sektoru maloprodaje u Republici Srbiji, a koje je bilo predmet međunarodne akvizicije. U cilju obezbeđenja adekvatne reprezentativnosti uzorka, upitnik je distribuiran u svim delovima preduzeća širom Republike Srbije. Rezultati istraživanja su pokazali da sve dimenzije transformacionog liderstva pozitivno utiču na postakvizicione performanse preduzeća. Najveći uticaj ima dimenzija transformacionog liderstva - individualna razmatranja, dok najmanji stepen uticaja ima dimenzija intelektualna stimulacija.
\end{abstract}

Ključne reči: transformaciono liderstvo, dimenzije transformacionog liderstva, postakvizicione performanse, preuzeto preduzeće

JEL Classification: G34, M54, L25

\section{UVOD}

Poslednjih decenija, merdžeri i akvizicije predstavljaju primarne strategijske opcije koje preduzeća koriste kako bi, u sve konkurentnijem okruženju, osigurala

* Korespondencija: S. Savović, Ekonomski fakultet Univerziteta u Kragujevcu, Đ. Pucara 3, 34000 Kragujevac, Republika Srbija; e-mail: ssladjana@kg.ac.rs svoju poziciju (Faulkner, Teerikangas \& Jospeh, 2012). Merdžeri i akvizicije su kompleksni organizacioni događaji sa velikim brojem faktora koji mogu voditi uspehu ili neuspehu. Jedan od razloga zašto dolazi do neuspeha merdžera i akvizicija je zanemarivanje pitanja koja se odnose na ljudske resurse. Transakcije merdžera i akvizicija predstavljaju traumatične događaje za zaposlene, usled mogućih otpuštanja, uvođenja novih stilova upravljanja i novih pravila 
poslovanja. Merdžeri i akvizicije povećavaju neizvesnost za zaposlene, što dovodi do manje posvećenosti poslu i izvršavanju organizacionih zadataka. Otuda je od velikog značaja obezbediti adekvatno transformaciono liderstvo, posebno $\mathrm{u}$ kritičnoj postakvizicionoj fazi (Waldman \& Mansour, 2009), kako bi se pružila neophodna podrška i pomoć zaposlenima, i pomoglo u prevazilaženju problema. Transformaciono liderstvo podrazumeva "fundamentalne promene vrednosti, ciljeva i aspiracija zaposlenih, čime se oni podstiču da izvršavaju poslove zato što su u skladu sa njihovim vrednostima, a ne zato što očekuju nagradu za svoje napore“ (MacKenzie, Podsakoff \& Rich, 2001, 118). Transformacioni lideri imaju „sposobnosti i veštine da motivišu zaposlene na nov način razmišljanja, rušeći postojeće paradigme i kreirajući nove" (Savović, 2012, 200).

Četiri dimenzije transformacionog liderstva su inspiraciona motivacija, harizma ili idealizovani uticaj, individualna razmatranja i intelektualna stimulacija (Bass, 1999). Inspiraciona motivacija je stepen $\mathrm{u}$ kome lider artikuliše viziju koja je privlačna i inspirativna zaposlenima. Idealizovani uticaj je sposobnost lidera da izazove ponos, veru i poštovanje (Covin, Kolenko, Sightler \& Tudor, 1997). Individualna razmatranja odnose se na poklanjanje pažnje svakom zaposlenom, odnosno, bavljenje njegovim konkretnim problemima. Intelektualna stimulacija je ponašanje lidera koje razvija sposobnost i sklonost zaposlenih da razmišljaju o problemima na nov način (Rafferty \& Griffin, 2004). Transformacioni lideri treba zaposlenima da pruže jasnu sliku ili viziju budućnosti, inspirišu ih i obezbede neophodnu podršku i pomoć prilikom suočavanja sa izazovima promena, utičući na taj način na povećanje njihove posvećenosti efikasnijem obavljanju zadataka.

Istraživanje odnosa između transformacionog liderstva i performansi predmet je interesovanja velikog broja autora (Judge \& Piccolo, 2004; Menges, Walter, Vogel \& Bruch 2011; Carter, Armenakis, Field \& Mossholder 2012; Braun, Peus, Weisweiler \& Frey, 2013). Međutim, mali broj studija istraživao je uticaj transformacionog liderstva na postakvizicione performanse (Nemanich \& Keller, 2007; Nemanich \& Vera, 2009). Ove studije su, najvećim delom, fokusirane na razvijene tržišne ekonomije, dok su istraživanja u tranzicionim ekonomijama ograničena.

Predmet istraživanja ovog rada jeste transformaciono liderstvo i njegovi efekti na postakvizicione performanse.

Cilj rada je ispitati kako različite dimenzije transformacionog liderstva utiču na postakvizicione performanse preuzetog preduzeća.

Polazeći od definisanog predmeta i cilja istraživanja, osnovna naučna hipoteza rada je da dimenzije transformacionog liderstva pozitivno utiču na postakvizicione performanse preuzetog preduzeća.

Imajući u vidu postavljeni predmet, cilj istraživanja, kao i osnovnu istraživačku hipotezu, u radu je primenjena kvalitativna i kvantitativna metodologija. Primena kvalitativne metodologije ogleda se $u$ konsultovanju relevantne literature kako bi se stvorila teorijska osnova za primenu kvantitativne metodologije pomoću koje su testirane istraživačke hipoteze. Naglasak na kvantitativnoj metodologiji evidentan je $\mathrm{u}$ literaturi o merdžerima i akvizicijama, budući da omogućava sagledavanje odnosa između različitih nezavisnih i zavisnih varijabli (najčešće postakvizicionih performansi) (Schoenberg, 2006). Empirijsko istraživanje sprovedeno je na primeru preduzeća koje posluje kao lider u maloprodaji, a koje je bilo predmet međunarodne akvizicije 2011. Prikupljanje podatka sprovedeno je korišćenjem strukturiranog upitnika koji je distribuiran zaposlenima. Analiza podataka izvršena je korišćenjem različitih kvantitativnih statističkih metoda i tehnika. Izvršena je analiza pouzdanosti i interne konzistentnosti varijabli. Za testiranje hipoteza korišćena je hijerarhijska regresija.

Rad je strukturiran u pet sekcija. Nakon uvoda, u radu se daje pregled literature čime se postavlja osnova za formulisanje istraživačkih hipoteza. U trećoj sekciji objašnjena je metodologija istraživanja. Nakon toga, $u$ četvrtoj sekciji predstavljeni su rezultati empirijskog istraživanja. Konačno, u petoj sekciji dati su zaključci, istaknut doprinos rada i ukazano je na pravce budućih istraživanja. 


\section{PREGLED LITERATURE}

\section{Koncept transformacionog liderstva}

Između različitih perspektiva liderstva, transformaciono liderstvo se često povezuje sa menadžerskom efektivnošću tokom organizacionih promena (Carter et al, 2012). Transformaciono liderstvo se pojavilo 80-tih godina XX-og veka, sa velikim talasom organizacionih promena koje je trebalo ostvariti u kratkom roku i koje je bilo moguće izvesti samo uz izuzetno sposobne lidere. $\mathrm{U}$ situacijama kompleksnih promena, transformaciono liderstvo je efektivnije od transakcionog liderstva, koje predstavlja konvencionalniji stil liderstva. Transakcioni lideri utiču na zaposlene nagrađujući njihova ostvarenja i preduzimajući korektivne akcije ukoliko je to neophodno. Transformaciono liderstvo se najčešće koristi da opiše lidere koji se suočavaju sa izazovima i motivišu zaposlene da razmišljaju drugačije o njihovim procesima, procedurama, primeni znanja i ishodima odluka. Zadatak ovih lidera je da komuniciraju dobro artikulisanu viziju, stvaraju osećaj pripadnosti i podstiču zaposlene na prilagođavanje promenama. B. Bass (1999) ističe da transformaciono i transakciono liderstvo jesu odvojeni koncepti, ali da je najbolje da lideri imaju osobine i transformacionih i transakcionih lidera.

Transformacioni lideri komuniciraju viziju koja stvara entuzijazam kod zaposlenih (inspiraciona motivacija), pružaju podršku podređenima putem svoje harizme (idealizovani uticaj), posvećuju pažnju individualnim potrebama zaposlenih i reaguju na njihove probleme (individualna razmatranja), ohrabruju različita razmišljanja i inovativnost unutar organizacije (intelektualna stimulacija). Inspiraciono liderstvo ima za cilj da izgradi želju za izvrsnošću i prihvatanje promena sa entuzijazmom i poverenjem (Sitkin \& Pablo, 2005). Transformacioni lideri prenose viziju sa jakim emotivnim nabojem, koja predstavlja neophodnu pokretačku snagu bitnu za obezbeđenje visoke angažovanosti i posvećenosti zaposlenih (Stojanović Aleksić, 2006). Dodatno, inspiraciono liderstvo $\mathrm{u}$ preuzetom preduzeću povećava posvećenost zaposlenih, jer im olakšava razumevanje novog organizacionog okruženja (Schweizer \& Patzelt, 2012). Razvijajući osećaj da su izazovni ciljevi dostižni i da preduzeće ima sposobnosti da ih ostvari, lideri su u stanju da zaposlene motivišu da sa entuzijazmom prihvataju sve eventualne prepreke kako bi ih lakše savladali.

Harizma (idealizovani uticaj) se može definisati kao sposobnost da se stvori velika simbolička moć sa kojom zaposleni žele da se identifikuju (Covin et al, 1997). Zaposleni osećaju divljenje, poštovanje i poverenje prema harizmatičnom lideru. D. Nadler i M. Tushman (1990) opisuju "harizmatičnog lidera" kao nekoga ko poseduje posebne kvalitete i sposobnost da mobiliše i održi aktivnost u organizaciji putem konkretnih aktivnosti i ličnih osobina. Harizmatični lideri inspirišu zaposlene, pokazuju odlučnost pri ostvarivanju promena, ulivaju poverenje i predstavljaju model ugledanja, čime utiču na povećanje posvećenosti zaposlenih organizaciji i njihovoj većoj motivisanosti ka ostvarivanju boljih performansi (Waldman \& Mansour, 2009).

Individualno razmatranje je stepen $\mathrm{u}$ kome lider posvećuje pažnju potrebama zaposlenih, deluje kao mentor i reaguje na probleme i potrebe zaposlenih (Judge \& Piccolo, 2004). L. M. Marks i H. P. Mirvis (1986) ističu da je zaposlenima u preuzetim preduzećima neophodna podrška budući da prolaze kroz velike psihološke šokove tokom akvizicije. Obezbeđujući resurse, obuku, pružajući ohrabrenje i potrebne informacije svakom zaposlenom pojedinačno, lider radi na razvijanju osećanja prihvatanja, sigurnosti i lične efikasnosti.

Intelektualna stimulacija je stepen u kome se lider suočava sa pretpostavkama, preuzima rizik i nudi ideje zaposlenima. Lideri sa ovom osobinom stimulišu i ohrabruju kreativnost kod zaposlenih. Kreativno razmišljanje je od posebnog značaja budući da postoji potreba da se odbace rutine i norme ponašanja koje su postojale $\mathrm{u}$ prethodnoj organizaciji i usvoje nove navike. Obezbeđujući intelektualnu stimulaciju, transformacioni lideri ohrabruju zaposlene da usvajaju istraživački proces razmišljanja i da razmišljaju o starim problemima na nov način. Pokazujući visoka očekivanja i poverenje 
u sposobnost zaposlenih, transformacioni lideri utiču na razvijanje posvećenosti zaposlenih ostvarivanju dugoročnih ciljeva. Na ovaj način, pomera se fokus sa kratkoročnih ciljeva i neposrednih rešenja, ka dugoročnim ciljevima i fundamentalnim rešenjima (Jung, Chow \& Wu, 2003) .

\section{Merenje postakvizicionih performansi}

Poslednjih dvadesetak godina, veliki broj studija je bio usmeren na istraživanje postakvizicionih performansi (Ravensraft \& Scherer, 1989; Morosini \& Singh, 1994; Lu, 2004; Schoenberg, 2006; Martyinova \& Renneboog, 2008). Ove studije oslanjale su se na različita alternativna merila postakvizicionih performansi, a najčešć na merila zasnovana na promeni cena akcija (Sudarsanam \& Mahate, 2003; Tuch \& O'Sullivan, 2007), računovodstvena merila (Ravensraft \& Scherer, 1989; Healy, Palepu \& Ruback, 1992; Lu, 2004), kao i merila zasnovana na subjektivnim procenama menadžera (Datta, 1991; Homburg \& Bucerius, 2006).

Studije koje koriste merila zasnovana na promeni cena akcija pripadaju tzv. studijama događaja, koje prate promene cene akcija $\mathrm{u}$ danima ili mesecima oko objave preuzimanja (kratkoročne studije), odnosno, kretanje cena akcija u dugom vremenskom periodu, obično više meseci ili godina nakon preuzimanja (dugoročne studje). Metodologija studija događaja „,polazi od pretpostavke da je tržište kapitala efikasno, odnosno, da cene akcija blagovremeno i nepristrasno reaguju na nove informacije i da promena u ceni akcija uključenih preduzeća odražava vrednost događaja preuzimanja" (Cordin \& Christman, 2002, citirano u Savović, 2016, 82). Model praćenja cena akcija baziran je na utvrđivanju tzv. abnormalnog prinosa. Značajan problem ovih merila performansi je nemogućnost primene kod preduzeća koja nisu kotirana na berzi. Pored toga, promene cene akcija ne moraju biti rezultat samo preuzimanja, već mogu biti uzrokovane drugim faktorima. Dodatno, postojanje perioda u kojima se ne trguje akcijama, kao i preklapanje više događaja preuzimanja može narušiti pouzdanost dugoročnih studija (Tuch \& O'Sullivan, 2007). Rezultati ovih studija pokazuju da akcionari preuzetih preduzeća u proseku ostvaruju pozitivne prinose, budući da im se isplaćuju visoke premije za preuzimanje. Akcionari preuzetih preduzeća ostvaruju premije, u proseku 20$40 \%$ u odnosu na cenu akcija pre objavljivanja ponude (Goergen \& Renneboog, 2004). A. Fatemi, I. Fooladi i N. Garehkoolchian (2017) istražuju kratkoročne efekte akvizicija u Japanu, i na osnovu rezultata istraživanja zaključuju da akcionari preuzetih preduzeća ostvaruju pozitivne prinose. Rezultati $u$ pogledu uticaja na akcionare preduzeća-kupca nisu jednoznačni. Određene studije pokazuju pozitivne prinose, dok druge izveštavaju o negativnim prinosima. Rezultati studije J. Li, P. Li i B. Wang (2016, 481) pokazali su da se kod međunarodnih akvizicija „izvršenih od strane kineskih preduzeća, cene akcija preduzeća-kupca povećavaju u proseku za 2-4\%." $S$ druge strane, rezultati studije S. Sudarsanam i A. Mahate (2003) ukazuju na postojanje negativnih prinosa akcionara preduzeća-kupca u kratkom roku.

Merila performansi na bazi promene cena akcija ne mogu da izmere uticaj preuzimanja na troškove, prihode, profite i novčane tokove, iako je strategija preuzimanja, generalno, usmerena na poboljšanje ovih varijabli kao rezultat očekivanog jačanja konkurentske pozicije. Otuda, poseban značaj imaju računovodstvena merila performansi. Računovodstvene studije analiziraju računovodstvene performanse preduzeća, upoređujući određene pokazatelje, najčešće stopu prinosa na ukupno uložena sredstva, stopu prinosa na kapital, stopu poslovnog dobitka i stopu neto dobitka, pre i nakon preuzimanja. I. Thanos i V. Papadakis $(2012,120)$ kao glavnu prednost računovodstveno baziranih merila ističu da ona mere „stvarne performanse na osnovu podataka iz zvaničnih finansijskih izveštaja, a ne očekivanja investitora vezana za budućnost". Glavne kritike usmerene ka primeni računovodstvenih merila performansi su da odražavaju performanse $\mathrm{u}$ prošlosti i da primena različitih računovodstvenih merila otežava upoređivanje rezultata istraživanja (Savović, 2016). Rezultati studija baziranih na računovodstvenim merilima performansi su različiti. R. Rao-Nicholson, J. Salaber i T. Hiep Cao $(2016,373)$ istraživali su postakvizicione performanse preduzeća u ekonomijama u razvoju i zaključili su da „dolazi do pogoršanja poslovnih performansi preduzeća 
tri godine nakon akvizicija“. D. S. Sharma i J. Ho (2002) analizirali su efekte australijskih akvizicija na računovodstvene performanse i pokazali da korporativne akvizicije ne dovode do poboljšanja postakvizicionih performansi. S druge strane, P. Guest, M. Bild i M. Runsten (2010), istražujući akvizicije u Velikoj Britaniji, pokazuju da dolazi do poboljšanja profitabilnosti poslovanja preduzeća u periodu nakon preuzimanja.

Treća grupa studija koristi subjektivne procene menadžera u merenju postakvizicionih performansi. Ovakav pristup primenjuje se kada je teško dobiti objektivne podatke. Menadžeri popunjavaju upitnike procenjujući finansijske i nefinansijske performanse na bazi njihovog ličnog razumevanja tekuće situacije u preduzeću. Ovakve procene performansi mogu biti stvar ličnih predrasuda menadžera kada jedan ispitanik procenjuje performanse preduzeća. Otuda je nužno u proceni performansi koristiti veći broj ispitanika. Takođe, neophodno je obezbediti da menadžeri koji procenjuju performanse dobro poznaju sitauciju u preduzeću i da su upoznati sa kompletnom istorijom akvizicije. Ako su ovi uslovi ispunjeni, procene performansi od strane menadžera imaju prednost $u$ odnosu na ostale pristupe merenju performansi jer omogućavaju višedimenzionalno merenje postakvizicionih performansi, obuhvatanjem i finansijskih i nefinansijskih performansi. Na osnovu pregleda literature, odnosno, studija koje su koristile subjektivna merila performansi, I. Thanos i V. Papadakis (2012) zaključuju da u proseku kod 45-60\% akvizicija ne dolazi do poboljšanja postakvizicionih performansi.

\section{Transformaciono liderstvo $\mathrm{i}$ postakvizicione performanse}

Transformaciono liderstvo utiče na smanjivanje neizvesnosti i razvijanje osećanja prihvatanja kod zaposlenih, čime se povećava njihova posvećenost organizaciji, što predstavlja bitan preduslov za unapređenje poslovnih performansi. Određene studije istraživale su uticaj transformacionog liderstva i performansi preduzeća (Garcia-Morales, LlorensMontes \& Verdu-Jover, 2008; Wang, Tsui \& Xin, 2011).
U studiji V. J. Garcia-Morales, F. J. Llorens-Montes i A. J. Verdu-Jover (2008) potvrđeno je da transformaciono liderstvo doprinosi poboljšanju organizacionih performansi. Studija T. Wang-a, A. Tsui-a i K. Xin-a, (2011) pokazala je da transformaciono liderstvo utiče pozitivno na performanse preduzeća.

Određene studije istraživale su vezu između različitih dimenzija transformacionog liderstva i performansi (Podsakoff, MacKenzie, Moorman \& Fetter, 1990; Howell \& Avolio, 1993; Nemanich \& Keller, 2007; Rafferty \& Griffin, 2014; Babić, Savović \& Domanović, 2014). L. Nemanich i R. Keller (2007) istraživali su uticaj transformacionog liderstva na prihvatanje akvizicija, satisfakciju zaposlenih poslom, kao i na performanse zaposlenih. Rezultati studije pokazali su da transformaciono liderstvo ostvaruje pozitivan uticaj na sve zavisne varijable. Dimenzija transformacionog liderstva idealizovani uticaj najviše utiče na prihvatanje akvizicija od strane zaposlenih, dok dimenzija individualna razmatranja ostvaruje najveći uticaj na performanse zaposlenih. Studija koju su sproveli A. Rafferty i M. Griffin (2004) pokazala je da inspiraciono komuniciranje, kao i intelektualna stimulacija od strane lidera, pozitivno utiču na posvećenost zaposlenih organizaciji. Iako intelektualna stimulacija može povećati nivo stresa na radnom mestu (Podsakoff et al, 1990) zaposleni se ipak osećaju vrednijim kada se ohrabruju da daju doprinos organizaciji. Prenošenje pozitivnih i ohrabrujućih poruka pozitivno utiče na emocionalnu povezanost zaposlenih sa organizacijom i jača njihovu veru $\mathrm{u}$ sopstvene sposobnosti izvršavanja zadataka. V. Babić, S, Savović i V. Domanović (2014) naglašavaju da inspirisanje i podsticanje zaposlenih od strane lidera, kao i reagovanje na probleme zaposlenih, odnosno, individualno razmatranje zaposlenih pozitivno utiče na postakvizicione performanse. J. M. Howell i B. J. Avolio (1993) ističu da intelektualna stimulacija od strane lidera pozitivno utiče na performanse kada postoji klima koja podržava inovativnost. Intelektualna stimulacija povećava sposobnost zaposlenih da osmisle, shvate i analiziraju probleme i poboljšaju kvalitet rešenja, što se pozitivno odražava na performanse preduzeća. 
U skladu sa pregledom relevantne literature, formulisane su istraživačke hipoteze koje pretpostavljaju postojanje pozitivnog uticaja dimenzija transformacionog liderstva na postakvizicione performanse.

H1: Transformacioni lideri, inspirisanjem i podsticanjem zaposlenih, pozitivno utiču na postakvizicione performanse preuzetog preduzeća.

H2: Transformacioni lideri, putem svoje harizme i ohrabrivanjem zaposlenih na prihvatanje promena, pozitivno utiču na postakvizicione performanse preuzetog preduzeća.

H3: Transformacioni lideri, pružanjem neposredne podrške zaposlenima, pozitivno utiču na postakvizicione performanse preuzetog preduzeća.

H4: Transformacioni lideri, intelektualnom stimulacijom i podsticanjem inovativnog razmišljanja kod zaposlenih, pozitivno utiču na postakvizicione performanse preuzetog preduzeća.

\section{METODOLOŠKI PRISTUP}

Istraživačke hipoteze biće testirane na primeru preduzeća koje je preuzeto 2011. Podaci su prikupljeni tokom 2013, kao deo širih istraživačkih napora. Pre sprovođenja istraživanja, kontaktiran je menadžment preduzeća kako bi se objasnili ciljevi istraživanja i dobilo odobrenje za distribuiranje upitnika zaposlenima. Menadžment tim je odobrio sprovođenje istraživanja, uz uslov da istraživač dostavi rezultate istraživanja preduzeću. Budući da je menadžment preduzeća prepoznao značaj sprovođenja ovakvog istraživanja i za sopstvene potrebe, postarao se da se obezbedi reprezentativnost uzorka, distribucijom upitnika u svim delovima Republike Srbije u kojima preduzeće posluje. Preduzeće ima 6356 zaposlenih, a istraživanje je sprovedeno na uzroku od 344 zaposlenih, što predstavlja $5,41 \%$ od ukupnog broja zaposlenih. Kao što je prikazano u Tabeli 1, u uzorku ima više žena (56,4\%) nego muškaraca $(28,2 \%)$, dok za $15,4 \%$ ispitanika nedostaju podaci. Posmatrano prema starosnoj strukturi, najbrojnije kategorije ispitanika su u starosnim grupama od 26 do 35 godina $(33,1 \%)$ i od 36 do 45 godina (30,8\%). Ukoliko se posmatraju godine radnog staža, uočava se ravnomerna zastupljenost ispitanika sa kraćim radnim stažom: do pet godina $(20,4 \%)$, od 6-10 godina $(20,9 \%)$ i od $11-15$ godina $(19,8 \%)$, dok je učešće ispitanika sa dužim radnim stažom: od 16-25 godina (12,5\%) i preko 25 godina $(15,1 \%)$ nešto manje. U strukturi uzorka dominiraju ispitanici na izvršnim pozicijama $(64,2 \%)$ u odnosu na ispitanike na menadžerskim pozicijama (12,5\%), dok za 23,3\% ispitanika nedostaju podaci.

Tabela 1 Karakteristike uzorka

\begin{tabular}{lrc}
\hline Varijable & Frekvencija & $\begin{array}{c}\text { \% od ukupnog } \\
\text { broja }\end{array}$ \\
\hline Pol & & \\
Muškarci & 97 & 28,2 \\
Žene & 194 & 56,4 \\
Bez odgovora & 53 & 15,4 \\
\hline Starost & & \\
18-25 & 20 & 5,8 \\
$26-35$ & 114 & 33,1 \\
$36-45$ & 106 & 30,8 \\
$46-55$ & 54 & 15,7 \\
$>55$ & 9 & 2,6 \\
Bez odgovora & 1 & 11,9 \\
\hline Godine radnog staža & & \\
$<5$ & 70 & 20,4 \\
$6-10$ & 72 & 20,9 \\
11-15 & 68 & 19,8 \\
16-25 & 43 & 12,5 \\
$>25$ & 52 & 15,1 \\
Bez odgovora & 39 & 11,3 \\
\hline Pozicija & & \\
Menadžment (top, & 43 & 12,5 \\
srednji i operativni) & 221 & 64,2 \\
Izvršne pozicije & $<$ & 23,3 \\
Nedostaju podaci & &
\end{tabular}

Izvor: Autor 
Podaci su analizirani u statističkom paketu za društvene nauke (Statistical Package for Social Sciences - SPSS, Version 20.0). Merenje pouzdanosti i interne konzistentnosti varijabli izvršeno je pomoću Cronbach's Alpha koeficijenta. Deskriptivna statistika korišćena je za merenje centralne tendencije (aritmetička sredina) i merenje varijabilnosti (standardna devijacija). Testiranje istraživačkih hipoteza izvršeno je putem hijererhijske regresije.

Nezavisne varijable, odnosno, dimenzije transformacionog liderstva merene su na osnovu modifikovanog Multifactor Leadership Questionnaire (Bass \& Avolio, 2000). Ove varijable procenjivali su svi zaposleni $(n=344)$. Zavisna varijabla Postakvizicione performanse merena je putem subjektivnih percepcija menadžera koji su izražavali stepen slaganja sa devet iskaza vezanih za finansijske i nefinansijske performanse. Ovu varijablu nisu procenjivali svi zaposleni, već samo zaposleni na menadžerskim pozicijama $(n=43)$. Korišćena je petostepena Likertova skala, koja pokazuje stepen slaganja ispitanika sa iznetim iskazima. Ispitanicima su na raspolaganju stajali odgovori od 1 - uopšte se ne slažem do 5 - u potpunosti se slažem. U Tabeli 2 prikazane su varijable modela i iskazi na osnovu kojih su varijable merene.

Tabela 2 Varijable modela i iskazi

\begin{tabular}{|c|c|}
\hline Varijable & Iskazi \\
\hline \multicolumn{2}{|c|}{ Nezavisne varijable } \\
\hline $\begin{array}{l}\text { Inspiraciona } \\
\text { motivacija }\end{array}$ & $\begin{array}{l}I_{1}: \text { Nadređeni menadžeri su sa optimizmom govorili o budućnosti preduzeća. } \\
I_{2}: \text { Nadređeni menadžeri objašnjavali su zaposlenima šta je zajednička vizija, i kakvi su pravci razvoja } \\
\text { preduzeća. } \\
I_{3}: \text { Nadređeni menadžeri pomagali su zaposlenima da shvate zašto je za preduzeće bitno da bude } \\
\text { preuzeto od strane drugog preduzeća. } \\
I_{4}: \text { Dobijanje relevantnih informacija od nadređenih menadžera, koje su se odnosile na buduće } \\
\text { planove pomoglo mi je u prevazilaženju problema tokom procesa promena. }\end{array}$ \\
\hline $\begin{array}{l}\text { Idealizovani } \\
\text { uticaj }\end{array}$ & $\begin{array}{l}I_{i}: \text { Nadređeni menadžeri služili su kao pozitivni uzori i inspirisali su zaposlene na sprovođenje } \\
\text { promena. } \\
I_{2}: \text { Nadređeni menadžeri svojim primerom delovali su podsticajno na zaposlene. } \\
I_{1}^{3}: \text { Nadređeni menadžeri su ohrabrivali zaposlene da prihvate promene. } \\
I_{4}^{3}: \text { Nadređeni menadžeri su naglašavali važnost i neophodnost sprovođenja promena u preduzeću. }\end{array}$ \\
\hline $\begin{array}{l}\text { Individualna } \\
\text { razmatranja }\end{array}$ & $\begin{array}{l}I_{1}: \text { Neposredna podrška menadžera pomogla mi je da prevaziđem probleme tokom procesa promena. } \\
I_{2}: \text { Kao podrška zaposlenima u prilagođavanju novim okolnostima u preduzeću su organizovani } \\
\text { različiti programi obuke. } \\
I_{3}: \text { Obuka mi je pomogla u prevazilaženju problema tokom procesa promena. }\end{array}$ \\
\hline $\begin{array}{l}\text { Intelektualna } \\
\text { stimulacija }\end{array}$ & $\begin{array}{l}I_{1}: \text { Nadređeni menadžeri podsticali su inovativno razmišljanje kod zaposlenih. } \\
I_{2}: \text { Nadređeni menadžeri ohrabrivali su zaposlene da tragaju za novim načinima rešavanja određenih } \\
\text { problema. }\end{array}$ \\
\hline \multicolumn{2}{|l|}{ Zavisna varijabla } \\
\hline $\begin{array}{l}\text { Postakvizicione } \\
\text { performanse }\end{array}$ & 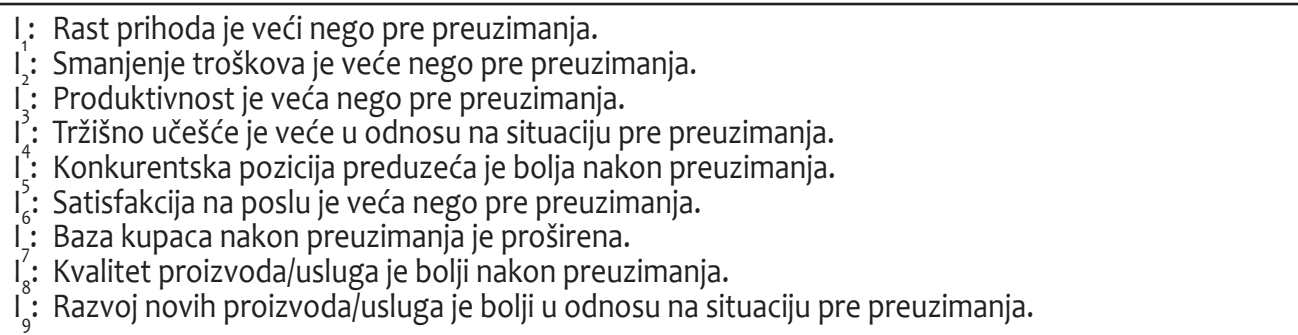 \\
\hline
\end{tabular}




\section{REZULTATI ISTRAŽIVANJA}

U Tabeli 3 prikazane su aritmetičke sredine, standardne devijacije i koeficijenti Cronbach's Alpha analiziranih varijabli. Vrednosti aritmetičkih sredina dimenzija transformacionog liderstva su iznad 3, što znači da su zaposleni relativno zadovoljni podrškom koju su dobijali od lidera. Najbolje su ocenjene dimenzije transformacionog liderstva Inspiraciona motivacija $(\mathrm{AS}=3,38)$ i Idealizovani uticaj $(\mathrm{AS}=$ 3,30), nešto lošije je ocenjena dimenzija Intelektualna stimulacija $\mathrm{AS}=3,16$, a najmanje dimenzija Individualna razmatranja (AS $=3,06)$. Ovo znači da su zaposleni bolje ocenili podršku lidera u smislu inspirisanja i podsticanja na prihvatanje promena, dok su manje bili zadovoljni podrškom lidera $u$ smislu podrške u prevazilaženju mogućih problema tokom procesa promena. Vrednost aritmetičke sredine varijable Postakvizicione performanse je ispod 3 (AS = 2,88), što znači da nije ostvareno zadovoljavajuće poboljšanje performansi u periodu nakon preuzimanja.

Tabela 3 Aritmetičke sredine, standardne devijacije i koeficijenti Cronbach's Alpha analiziranih varijabli

\begin{tabular}{|c|c|c|c|}
\hline Varijable & AS & S.D & $\begin{array}{c}\text { Cronbach's } \\
\text { Alpha }\end{array}$ \\
\hline Inspiraciona motivacija & 3,38 & 1,09 & 0,958 \\
\hline Idealizovani uticaj & 3,30 & 1,19 & 0,943 \\
\hline Individualna razmatranja & 3,06 & 1,17 & 0,910 \\
\hline Intelektualna stimulacija & 3,16 & 1,25 & 0,951 \\
\hline $\begin{array}{l}\text { Postakvizicione } \\
\text { performanse }\end{array}$ & 2,88 & 1,18 & 0,958 \\
\hline
\end{tabular}

Izvor: Autor

Rezultati analize pouzdanosti i interne konzistentnosti varijabli su pokazali da sve varijable poseduju visok nivo pouzdanosti i interne konzistentnosti, budući da su prihvatljive vrednosti Cronbach's Alpha koeficijenta iznad 0,7. Najviši stepen pouzdanosti karakterističan je za postakvizicione performanse $(\alpha=0,958)$, ali je i za sve ostale varijable karakterističan visok nivo pouzdanosti (intelektualna stimulacija: $\alpha=0,951$, inspiraciona motivacija: $\alpha=0,943$, idealizovani uticaj: $\alpha=0,902$ i individualna razmatranja: $\alpha=0,910$ ).

U Tabeli 4 prikazani su rezultati regresionih analiza, kojima je testiran uticaj različitih dimenzija transformacionog liderstva na postakvizicione performanse preduzeća. Prva hipoteza testira uticaj inspiracione motivacije na postakvizicione performanse. Model je statistički značajan ( $F=$ 33,801; $p=0,00$ ) i objašnjava $45,7 \%$ varijanse zavisne promenljive (adjusted $\mathrm{R}^{2}=0,457$ ). Rezultati regresione analize pokazuju da prva dimenzija transformacionog liderstva (inspiraciona motivacija) pozitivno utiče na postakvizicione performanse preduzeća $(\beta=0,686$; $p$ $=0,00)$. Na osnovu dobijenih rezultata, hipoteza $\mathrm{H} 1$ se može prihvatiti. Rezultati pokazuju da inspirisanje zaposlenih od strane transformacionih lidera pozitivno utiče na postakvizicione performanse preuzetog preduzeća.

Druga hipoteza testira uticaj druge dimenzije transfomacionog liderstva (idealizovani uticaj) na postakvizicione performanse preduzeća. Model je statistički značajan ( $F=24,055 ; p=0,00)$ i objašnjava $37,8 \%$ varijanse zavisne promenljive (adjusted $\mathrm{R}^{2}=$ 0,378). Rezultati regresione analize pokazuju da druga dimenzija transformacionog liderstva (idealizovani uticaj) pozitivno utiče na postakvizicione performanse preduzeća $(\beta=0,628 ; p=0,00)$. Imajući $u$ vidu rezultate analize hipoteza H2 se može prihvatiti. Pružanjem ličnog pozitivnog primera i ohrabrivanjem zaposlenih na prihvatanje promena transformacioni lideri pozitivno utiču na postakvizicione performanse preuzetog preduzeća.

Treća hipoteza testira uticaj treće dimenzije transformacionog liderstva (individualna razmatranja) na postakvizicione performanse preduzeća. Model je statistički značajan ( $\mathrm{F}=40,842$; $\mathrm{p}=$ $0,00)$ i objašnjava $51,2 \%$ varijanse zavisne promenljive (adjusted $\mathrm{R}^{2}=0,512$ ). Rezultati regresione analize pokazuju da treća dimenzija transformacionog liderstva (individualna razmatranja) pozitivno 
Tabela 4 Uticaj dimenzija transformacionog liderstva na postakvizicione performanse

\begin{tabular}{lcccccc}
\hline & $\mathrm{B}$ & $\mathrm{SE}$ & $\beta$ & $\mathrm{R} 2$ & $\begin{array}{c}\text { Prilagođeno } \\
\mathrm{R} 2\end{array}$ & $\mathrm{~F}$ \\
\hline Inspiraciona motivacija & 0,608 & 0,105 & $0,686^{* *}$ & 0,471 & 0,457 & $33,801^{* *}$ \\
Idealizovani uticaj & 0,526 & 0,107 & $0,628^{* *}$ & 0,394 & 0,378 & $24,055^{* *}$ \\
Individualna razmatranja & 0,676 & 0,106 & $0,724^{* *}$ & 0,525 & 0,512 & $40,842^{* *}$ \\
Intelektualna stimulacija & 0,466 & 0,113 & $0,555^{* *}$ & 0,308 & 0,290 & $16,921^{* *}$ \\
\hline
\end{tabular}

** Rezultat je statistički značajan na nivou $0,01(p<0,01)$

Izvor: Autor

utiče na postakvizicione performanse preduzeća $(\beta=0,724 ; p=0,00)$. Prema dobijenim rezultatima, analize hipoteza H3 se može prihvatiti. Pružanjem neposredne podrške zaposlenima, transformacioni lideri pozitivno utiču na postakvizicione performanse preuzetog preduzeća.

Četvrta hipoteza testira uticaj četvrte dimenzije transformacionog liderstva (intelektualna stimulacija) na postakvizicione performanse preduzeća. Model je statistički značajan $(F=16,921 \mathrm{p}=0,00)$ i objašnjava $29.0 \%$ varijanse zavisne promenljive (adjusted $\mathrm{R}^{2}$ $=0,290)$. Rezultati regresione analize pokazuju da četvrta dimenzija transformacionog liderstva (intelektualna stimulacija) pozitivno utiče na postakvizicione performanse preduzeća $(\beta=0,555$; $p=0,00)$. Na osnovu rezultata istraživanja, hipoteza H4 se može prihvatiti. Intelektualnom stimulacijom i podsticanjem inovativnog razmišljanja kod zaposlenih transformacioni lideri pozitivno utiču na postakvizicione performanse preuzetog preduzeća.

\section{ZAKLJUČAK}

U uslovima kompleksnih promena, kao što je proces preuzimanja preduzeća, transformaciono liderstvo predstavlja jedan od ključnih pokretača organizacionih performansi. Transformacioni lideri komuniciraju viziju koja stvara entuzijazam kod zaposlenih, pružaju podršku zaposlenima putem svog karaktera (harizme), pružaju podršku svakom zaposlenom pojedinačno putem mentorstva i podučavanja, ali ohrabruju i različita razmišljanja i inovativnost unutar organizacije. $\mathrm{Na}$ ovaj način deluje se u pravcu otklanjanja neizvesnosti kod zaposlenih i razvijanja osećanja poverenja i zajedničke povezanosti.

Rezultati istraživanja su pokazali da dimenzije transformacionog liderstva ostvaruju pozitivan uticaj na postakvizicione performanse. Na osnovu rezultata analize može se zaključiti da transformacioni lideri inspirisanjem zaposlenih i širenjem optimizma, pružanjem pozitivnog primera, pružanjem neposredne podrške zaposlenima kao i ohrabrivanjem da tragaju za novim načinima rešavanja problema, doprinose njihovoj posvećenosti poslu i zadacima koje obavljaju, što pozitivno utiče na postakvizicione performanse preuzetog preduzeća. Ovi zaključci su konzistentni sa zaključcima drugih istraživanja (Howell \& Avolio, 1993; Rafferty \& Griffin, 2004; Nemanich \& Keller, 2007), koja su potvrdila postojanje pozitivnog uticaja dimenzija transformacionog liderstva na performanse preduzeća. Razlika postoji jedino u pogledu veličine uticaja različitih dimenzija transformacionog liderstva na performanse preduzeća.

Na osnovu rezultata istraživanja, može se zaključiti da su zaposleni pozitivno procenili podršku od strane transformacionih lidera. Zaposleni pokazuju veći stepen zadovoljstva kada je u pitanju podrška lidera, u smislu inspirisanja i podsticanja na prihvatanje 
promena, dok je stepen zadovoljstva manji kada je u pitanju podrška lidera u prevazilaženju mogućih problema tokom procesa promena (individualna razmatranja). Rezultati istraživanja su pokazali da postakvizicione performanse $u$ posmatranom preduzeću nisu na zadovoljavajućem nivou. Ovakav rezultat delimično se može objasniti upravo činjenicom da dimenzija transformacionog liderstva individualno razmatranje ostvaruje najveći uticaj na postakvizicione performanse, a da je upravo ona najlošije ocenjena.

Rezultati istraživanja imaju značajne teorijske i praktične implikacije. Rezultati istraživanja doprinose boljem razumevanju složenih dejstava transformacionog liderstva na postakvizicione performanse preuzetog preduzeća. Imajući u vidu činjenicu da su studije u oblasti tranformacionog liderstva uglavnom bile fokusirane na uticaj transformacionog liderstva na performanse, ova studija doprinosi popunjavanju jaza u literaturi, fokusirajući se na uticaj transformacionog liderstva na postakvizicione performanse. Dodatno, s obzirom na to da su istraživanja u tranzicionim ekonomijama ograničena, rezultati istraživanja doprinose proširivanju znanja iz oblasti transformacionog liderstva i postakvizicionih performansi u kontekstu tranzicionih ekonomija. Povezivanje rezultata empirijskog istraživanja sa postojećim rezultatima istraživanja u svetu, moguće je dati određene smernice menadžerima uključenim u procese preuzimanja preduzeća. Preduzeća koja prolaze kroz procese kompleksnih promena na upravljačkim pozicijama treba da selektuju i postavljaju pojedince koji imaju osobine transformacionih lidera. Ukoliko menadžeri ne poseduju takve osobine, treba organizovati edukacije i treninge kako bi im se pomoglo u razvijanju veština transformacionih lidera. Dodatno, budući da su rezultati pokazali da individualno razmatranje, odnosno, fokusiranje lidera na pružanje podrške svakom zaposlenom i reagovanja na njihove probleme ima najveći uticaj na postakvizicione performanse, a da je ova dimenzije nešto slabije ocenjena od strane zaposlenih, neophodno je da u budućem periodu menadžment posveti pažnju intenziviranju podrške zaposlenima. Posebno treba da posveti pažnju podršci u smislu reagovanja na probleme zaposlenih, pruži im svu neophodnu pomoć i organizuje obuke gde će moći da dobiju neophodno znanje kako bi zadatke koji se pred njih postavljaju mogli efikasnije da obavljaju. Studija pruža značajan doprinos poslovnoj politici preduzeća naglašavanjem da je za uspeh poslovanja u periodima promena, važno fokusirati se na ljudske resurse. Zaključci do kojih se došlo u ovoj studiji mogu poslužiti menadžerima da razviju neophodni nivo posvećenosti i poverenja zaposlenih potrebnih za ostvarivanje izazovnih ciljeva u budućnosti.

Glavno ograničenje ove studije odnosi se na činjenicu da je istraživanje sprovedeno $u$ jednom preduzeću. $\mathrm{Za}$ izvođenje generalnih zaključaka analizu treba sprovesti na većem uzorku preduzeća. Korisno bi bilo izvršiti komparativnu analizu u više preduzeća $\mathrm{u}$ postakvizicionom periodu kako bi se utvrdilo da li su performanse bolje $\mathrm{u}$ onim preduzećima $\mathrm{u}$ kojima postoji transformaciono liderstvo. Dodatno ograničenje ovog istraživanja je oslanjanje na samo jedan izvor podataka dobijen popunjavanjem upitnika. Otuda u budućim istraživanjima treba obezbediti dodatne izvore podataka, poput direktnih intervjua sa menadžerima i finansijskih izveštaja kako bi se obezbedila dublja analiza istraživanog problema. Još jedno ograničenje ogleda se u činjenici da je istraživanje sprovedeno samo dve godine nakon preuzimanja, što nije bio dovoljno dug period za sagledavanje ukupnih efekata preuzimanja. Očigledno je period nakon preuzimanja najkritičniji i da je upravo u ovom periodu najbitnija podrška lidera. Imajući u vidu napred navedeno ograničenje, buduća istraživanja treba da usvoje istraživački dizajn koji će omogućiti proučavanje efekata transformacionog liderstva na postakvizicione performanse suksecivno, $\mathrm{u}$ različitim vremenskim periodima, što bi podrazumevalo primenu longitudinalnih studija, čime bi se produbilo razumevanje istraživanog problema.

\section{ZAHVALNICA}

Ovaj rad je deo interdisciplinarnog istraživačkog Projekta (br. 41010), koji finansira Ministarstvo prosvete, nauke i tehnološkog razvoja Republike Srbije. 


\section{REFERENCE}

Babić, V., Savović, S., \& Domanović, V. (2014). Transformational leadership and post-acquisition performance in transitional economies. Journal of Organizational Change Management, 27(6), 856- 876. doi.org/10.1108/JOCM-02-2014-0028

Bass, B. (1999). Two decades of research and development in transformational leadership. European Journal of Work and Organizational Psychology, 8(1), 9-32. doi. org/10.1080/135943299398410

Bass, B. M., \& Avolio, B. J. (2000). MLQ Multifactor Leadership Questionnaire. Redwood City, CA: Mind Garden.

Braun, S., Peus, C., Weisweiler, S., \& Frey, D. (2013). Transformational leadership, job satisfaction, and team performance: A multilevel mediation model of trust. The Leadership Quarterly, 24(1), 270-283. doi.org/10.1016/j. leaqua.2012.11.006

Carter, M., Armenakis, A., Field, H., \& Mossholder, K. (2012). Transformational leadership, relationship quality, and employee performance during continuous incremental organizational change. Journal of Organizational Behavior, 34(7), 942-958. doi: 10.1002/job.1824

Cordin, M., \& Christman, P. (2002). A focus on resources in M\&A success: A literature review and research agenda to resolve two paradoxes. University of Virginia, 1-40. Retrieved October 10, 2014 from http://citeseerx.ist.psu.edu/ viewdoc/ download?doi=10.1.1.201.7773\&rep=rep1\&type=pdf

Covin, T., Kolenko, T., Sightler, K., \& Tudor, K. (1997). Leadership style and post-merger satisfaction. Journal of Management Development, 16(1), 22-33. doi.org/10.1108/02621719710155454

Datta, K. D. (1991). Organizational fit and acquisition performance - Effects of post-acquisition integration. In A. Risberg (Ed.). (2006). Mergers and Acquisitions A Critical Reader (pp. 53-69). London and New York: Taylor \& Francis Group. doi: 10.4324/9780203708071

Fatemi, A., Fooladi, I., \& Garehkoolchian, N. (2017). Gains from mergers and acquisitions in Japan. Global Finance Journal, 32, 166-178. doi.org/10.1016/j.gfj.2017.02.002

Faulkner, D., Teerikangas, S., \& Jospeh, R. (2012). The handbook of mergers and acquisitions. Oxford, Mississippi: Oxford University Press.
Garcia-Morales, V. J., Llorens-Montes, F. J., \& Verdu-Jover, A. J. (2008). The effects of transformational leadership on organizational performance through knowledge and innovation. British Journal of Management, 19(4), 299-319. doi: 10.1111/j.1467-8551.2007.00547.x

Goergen, M., \& Renneboog, L. (2004). Shareholder wealth effects of European domestic and cross-border takeover bids. European Financial Management, 10(1), 9-45. doi: 10.1111/j.1468-036X.2004.00239.x

Guest, P., Bild, M., \& Runsten, M. (2010). The effect of takeovers on the fundamental value of acquireres. Accounting and Business Research, 40(4). 333-352. doi.org/10.1080/ 00014788.2010.9663409

Healy, P. M., Palepu, K. G., \& Ruback, R. S. (1992). Does corporate performance improve after mergers? Journal of Financial Economics, 31(2), 135-175. doi.org/10.1016/0304405X(92)90002-F

Homburg, C., \& Bucerius, M. (2006). Is speed of integration really a success factor of mergers and acquisitions? An analysis of role of internal and external relatedness. Strategic Management Journal, 27(4), 347-367. doi: 10.1002/ smj.520.

Howell, J. M., \& Avolio, B. J. (1993). Transformational leadership, transactional leadership, locus of control, and support for innovation: Key predictors of consolidated business-unit performance. Journal of Applied Psychology, 78(6), 891-902. doi.org/10.1037/0021-9010.78.6.891

Judge, T., \& Piccolo, R. (2004). Transformational and transactional leadership: A meta-analytic test of their relative validity. Journal of Applied Psychology, 89(5), 755-768. doi: 10.1037/0021-9010.89.5.755

Jung, D., Chow, C., \& Wu, A. (2003). The role of transformational leadership in enhancing organizational innovation: Hypotheses and some preliminary findings. The Leadership Quarterly, 14(4-5), 525-544. doi.org/10.1016/ S1048- 9843(03)00050-X

Li, J., Li, P., \& Wang, B. (2016). Do cross-border acquisitions create value? Evidence from overseas acquisitions by Chinese firms. International Business Review, 25(2), 471-483. doi.org/10.1016/j.ibusrev.2015.08.003

Lu, Q. (2004). Do mergers destroy value? Evidence from failed bids. Working Paper. Kellogg School of Management, Northwestern University. 
MacKenzie, S., Podsakoff,P., \& Rich, G. (2001). Transformational and transactional leadership and salesperson performance. Journal of the Academy of Marketing Science, 29(2), 115-134. doi: 10.1177/03079459994506

Marks, L. M., \& Mirvis, H. P. (1986). The merger syndrome, psychology today. In A. Risberg (Ed.). (2006). Mergers and Acquisition A Critical Reader (pp. 149-154). London and New York: Taylor \& Francis Group.

Martynova, M., \& Renneboog, L. (2008). A century of corporate takeovers: What have we learned and where do we stand? Journal of Banking and Finance, 32(10), 2148-2177. doi.org/10.1016/j.jbankfin.2007.12.038

Menges, J., Walter, F., Vogel, B., \& Bruch, H. (2011). Transformational leadership climate: Performance linkages, mechanisms, and boundary conditions at the organizational level. The Leadership Quarterly, 22(5), 893-909. doi: 10.1016/j.leaqua.2011.07.010

Morosini, P., \& Singh, H. (1994). Post-cross-border acquisitions: Implementing 'national culture-compatible' strategies to improve performance. European Management Journal, 12(4), 390-400. doi: 10.1016/0263-2373(94)90025-6

Nadler, D., \& Tushman, M. (1990). Beyond the charismatic leader: Leadership and organizational change. California Management Review, 32(2), 77-97. doi.org/10.2307/41166606

Nemanich, L., \& Keller, R. (2007). Transformational leadership in an acquisition: A field study of employees. The Leadership Quarterly, 18(1), 49-68. doi: 10.1016/j.leaqua.2006.11.003

Nemanich, L., \& Vera, D. (2009). Transformational leadership and ambidexterity in the context of an acquisition. The Leadership Quarterly, 20(1), 19-33. doi: 10.1016/j. leaqua.2008.11.002

Podsakoff, P. M., MacKenzie, S. B., Moorman, R. H., \& Fetter, R. (1990). Transformational leader behaviors and their effects on followers' trust in leader, satisfaction, organizational citizenship behaviours. The Leadership Quarterly, 1(2), 107142. doi: 10.1016/1048-9843(90)90009-7

Rafferty, A., \& Griffin, M. (2004). Dimensions of transformational leadership: Conceptual and empirical extensions. The Leadership Quarterly, 15(3), 329-354. doi: 10.1016/j. leaqua.2004.02.009
Rao-Nicholson, R., Salaber, J., \& Hiep Cao, T. (2016). Longterm performandce of mergers and acquisitions in ASEAN countries. Research in International Business and Finance, 36, 373-387. doi.org/10.1016/j.ribaf.2015.09.024

Ravenscraft, D. J., \& Scherer, F. J. (1989). The profitability of mergers. International Journal of Industrial Organizations, 7(1), 101-116. doi.org/10.1016/0167-7187(89)90048-9

Savović, S. (2012). The importance of post-acquisition integration for value creation and success of mergers and acquisitions. Economic Horizons, 14(3), 195-207. doi: 10.5937/ ekonhor1203193S

Savović, S. (2016). Post-acquisition performance of acquired companies: Evidence from Republic of Serbia. Economic Annals, 61(209), 79-104. doi: 10.2298/EKA1609079S

Schoenberg, R. (2006). Measuring the performance of corporate acquisitions: An empirical comparison of alternative metrics. British Journal of Management, 17(4), 361370. doi: 10.1111/j.1467-8551.2006.00488.x

Schweizer, L., \& Patzelt, H. (2012). Employee commitment in the post-acquisition integration process: The effect of integration speed and leadership. Scandinavian Journal of Management, 28(4), 298-310. doi.org/10.1016/j. scaman.2012.02.003

Sharma, D. S., \& Ho, J. (2002). The impact of acquisitions on operating performance: Some Australian evidence. Journal of Business Finance $\mathcal{E}$ Accounting, 29(1-2), 155-200. doi. org/10.1111/1468-5957.00428

Sitkin, S., \& Pablo, A. (2005). The neglected importance of leadership in mergers and acquisitions. In G. K. Stahl, \& M. E. Mendenhall (Eds.). Mergers and Acquisitions. Managing Culture and Human Resource (pp. 208-223). Stanford, Calif: Stanford University Press.

Stojanović Aleksić, V. (2006). Liderstvo kao ključni faktor uspešnog sprovođenja organizacionih promena. Ekonomski horizonti, 8(1-2), 7-14.

Sudarsanam, S., \& Mahate, A. (2003). Glamour acquirers, method of payment and post-acquisition performance: the UK evidence. Journal of Business Finance and Accounting, 30(1-2), 299-341. doi: 10.1111/1468-5957.00494 
Thanos, I., \& Papadakis, V. (2012). Unbundling acquisition performance: how do they perform and how can this be measured? In D. Faulkner, S. Teerikangas, \& R. Jospeh, (Eds.). The Handbook of Mergers and Acquisitions (pp. 114-147). Oxford, Mississippi: Oxford University Press.

Tuch, C., \& O'Sullivan, N. (2007). The impact of acquisitions on firm performance: A review of the evidence. International Journal of Management Reviews, 9(2), 141-170. doi: 10.1111/j.1468-2370.2007.00206.x

Waldman, D. A., \& Mansour, J. (2009). Alternative forms of charismatic leadership in integration of mergers and acquisitions. The Leadership Quarterly, 20(2), 130-142. doi. org/10.1016/j.leaqua.2009.01.008
Wang, H., Tsui, A., \& Xin, K. (2011). CEO leadership behaviors, organizational performance, and employees' attitudes. The Leadership Quarterly, 22(1), 92-105. doi: 10.1016/j. leaqua.2010.12.009

Wang, H., Tsui, A., \& Xin, K. (2011). CEO leadership behaviors, organizational performance, and employees' attitudes. The Leadership Quarterly, 22(1), 92-105. doi:10.1016/j. leaqua.2010.12.009

Primljeno 16. juna 2017, nakon tri revizije,

prihvaćeno za publikovanje 23. avgusta 2017. Elektronska verzija objavljena 25. avgusta 2017.

Slađana Savovićje docent Ekonomskog fakulteta Univerziteta u Kragujevcu, na nastavnom predmetu Ekonomika preduzeća. Doktorirala je na Ekonomskom fakultetu Univerziteta u Kragujevcu. Oblasti njenog naučnog interesovanja su merdžeri i akvizicije, postakviziciona integracija i postakvizicione performanse. 


\title{
THE IMPACT OF DIMENSIONS OF TRANSFORMATIONAL LEADERSHIP ON POST-ACQUISITION PERFORMANCE OF ACQUIRED COMPANY
}

\author{
Sladjana Savovic \\ Faculty of Economics, University of Kragujevac, Kragujevac, The Republic of Serbia
}

\begin{abstract}
Mergers and acquisitions (M\&A) are the important mechanisms through which companies can achieve growth, gain access to new markets and diversify their activities. Although companies engage themselves in M\&As with optimism, empirical evidence shows that many M\&A transactions are not successful. Therefore, research is often focused on the identification of the ways to improve post-acquisition performance. One of the key success factors of M\&A is to provide adequate transformational leadership during the process of change, especially in the critical phase of the post-acquisition integration. A transformational leader should provide incentives and support to the employees in order for them to accept changes and focus on achieving challenging goals. This paper explores the impact of the different dimensions of transformational leadership on the post-acquisition performance based on the example of a company operating in the Republic of Serbia's retail sector, which was the subject of a cross-border acquisition. In order to ensure the adequate representativeness of the sample, a questionnaire was distributed in all parts of the company throughout the Republic of Serbia. The results of this study show that all the dimensions of transformational leadership positively impact post-acquisition performance. The "individual consideration" dimension of transformational leadership has the strongest impact on post-acquisition performance, whereas the "intellectual simulation" dimension has the weakest.
\end{abstract}

Keywords: transformational leadership, dimensions of transformational leadership, post-acquisition performance, acquired company

JEL Classification: G34, M54, L25 